\title{
Does patenting help or hinder open innovation? Evidence from new entrants in the solar industry
}

\section{Ann-Kristin Zobel ${ }^{1, *}$, Benjamin Balsmeier ${ }^{2}$ and Henry Chesbrough ${ }^{3}$}

${ }^{1}$ Group for Sustainability and Technology, Department of Management, Technology and Economics, ETH Zurich, Weinbergstrasse 56/58, CH-8092 Zürich, Switzerland. e-mail: azobel@ethz.ch, ${ }^{2}$ Faculty of Economics and Management, Technical University Freiberg, Schlossplatz 1, 09599 Freiberg, Germany. e-mail: benjamin.balsmeier@bwl.tu-freiberg.de and ${ }^{3}$ Garwood Center for Corporate Innovation, Haas School of Business, University of California Berkeley, Berkeley, CA 94720-1930, USA. e-mail: chesbrou@berkeley.edu

*Main author for correspondence.

\begin{abstract}
This article analyzes how the patent stock of new entrants in industries shaped by systemic innovations influences their subsequent openness in innovation. The results suggest that patenting increases new entrants' number of open innovation relationships, on average. This association, however, varies across relationships of differing technology intensity. While the effect of patenting is strongly positive for technology-intensive relationships, it becomes weaker as the technology intensity decreases, and turns negative for least technology-intensive relationships.
\end{abstract}

JEL classification: M13, M21.

The emergence of the phenomenon of open innovation (OI) has been accompanied by an active debate concerning whether and to what extent appropriation mechanisms-firms' approaches to protect their knowledge and capture value from their innovative activities-help or hinder OI. In this context, the role of formal intellectual property (IP) rights, and in particular patents, has been highlighted and particularly disputed (e.g., Chesbrough, 2003, 2006; West, 2006). ${ }^{1}$ Whereas a small number of empirical studies reveals a positive association between a firm's degree of openness in innovation and its preference for formal IP (Laursen and Salter, 2014; Hagedoorn et al., 2014; Hagedoorn and Zobel, 2015), other scholars highlight the risks of formal appropriation mechanisms for knowledge sharing in a collaborative context (e.g., von Hippel and von Krogh, 2006; Baldwin and von Hippel, 2011). Similarly, a number of scholars suggest that IP initially enables OI but may hinder openness in innovation if firms focus too much on formal

1 Literature has discussed a variety of formal and informal appropriation mechanisms and their roles in interorganizational relationships (e.g., Lawson et al., 2012; James et al., 2013; Henttonen et al., 2015). Our study focuses on formal IP in particular patents. Patenting has an outstanding position among formal IP strategies in the broader innovation literature (e.g., Cohen et al., 2000; Hall and Ziedonies, 2001; Somaya, 2012). Furthermore, due to Ol's inherent tension between knowledge protection and sharing (see also Laursen and Salter, 2014), patenting as a formal knowledge protection and isolating mechanism has been particularly disputed in the context of Ol (e.g., Chesbrough, 2006; Baldwin and von Hippel, 2011) and is, therefore, an interesting starting point for investigating associations between appropriation and 0 I. 
IP (West and Gallagher, 2006; Laursen and Salter, 2014). These conflicting arguments as well as inconclusive empirical results suggest that the role of formal IP in OI remains highly debated, requiring further research in this domain.

The question of whether or not formal IP enables OI is particularly important when innovations become systemic. When innovations are highly dependent on the joint effort of interdependent parties, the success of such innovations may be threatened if firms are unwilling or unable to exchange relevant knowledge. For example, innovation in the renewable energy sector is becoming increasingly distributed and interdependent, requiring a collective effort from large corporations, start-ups, governmental institutions, infrastructure agencies, and service providers (Kapoor and Furr, 2014; Overholm, 2014). Such collaborative efforts may be at risk if relevant parties fear that their knowledge is unprotected or if they lack appropriate means for transferring complex technological knowledge. Hence, a relevant question to be addressed is whether patenting enables firms in systemic industries to collaborate and, thereby, overcome joint innovation challenges. This fundamental question is of interest from both a policy as well as from a firm perspective. First, policy makers would like to accelerate innovative effort, in general, and encourage collaboration for addressing systemic challenges, such as, for example, carbon-free renewable energy. Second, firms operating in a systemic innovation context are often dependent on collaborative efforts for achieving radical innovations. Hence, from a firm perspective, it is important to know whether patenting-which involves a resource-intensive processenables or inhibits such collaborative efforts.

In this context, new entrants are identified as having the capacity for radical innovation (Van de Vrande et al., 2009; Lee et al., 2010) and as important players in shaping systemic innovations (Kapoor and Furr, 2014), making them an important unit of analysis. In the context of systemic innovations, patents facilitate the entry of small firms (Arora and Merges, 2004). Yet, new entrants often lack complementary innovation assets to develop and commercialize new technologies and, as a result, are more dependent on OI relationships in order to overcome their liability of smallness (Van de Vrande et al., 2009; Parida et al., 2012). For example, "Innovalight," a solar start-up that entered the market in 2002, based on proprietary technologies in silicon ink processes, quickly accumulated a patent stock of over 60 patents. Despite its strong proprietary technology platform, Innovalight is dependent on external partners to enable the development of high efficiency solar cells. First, in order to accelerate the development and production of silicon ink material it engaged in joint technology development with the National Renewable Energy Lab. Second, since Innovalight could not afford the capital costs to manufacture solar cells, it entered into relationships with solar cell manufacturers in order to convert its technologies into high-efficiency solar cells. Whether Innovalight's significant patent stock enabled or inhibited these relationships thus exemplifies our research question.

Beyond this general research question, we address two specific gaps in our current understanding of the association between formal IP and OI. First, while prior empirical research generates important insights regarding how general preferences related to IP and openness are correlated (Laursen and Salter, 2014; Hagedoorn et al., 2014; Hagedoorn and Zobel, 2015), we only have a limited understanding of what happens when firms actually receive IP rights. ${ }^{2}$ In this context, it is important to examine how firms' actual stock of IP influences their subsequent openness in innovation (Laursen and Salter, 2014). We address this gap by observing the actual receipt of patents and their effects on firms' subsequent OI activities. Second, in investigating associations between openness and IP, existing literature has focused on the external search breadth and depth of firms (Laursen and Salter, 2014; Hagedoorn et al., 2014; Hagedoorn and Zobel, 2015). Indeed, existing research often employs simple count variables of firms' external search channels (from self-reported data on Community Innovation Surveys), while the actual contents of more formal relationships in an OI framework remain relatively unexplored (a notable exception is Alexy et al. (2016) who directly measure different OI practices). It seems unlikely that one size fits all: interorganizational relationships likely vary by the kind of relationship in question. We argue that a prominent characteristic that varies widely across such OI relationships refers to the technology intensity of resources that are being exchanged between partners (Hagedoorn, 1993; Christensen et al., 2005; Du et al., 2014). Given this heterogeneity of relationships, it becomes a relevant question whether the association between OI and IP is of a uniform nature, or whether it differs across relationships that vary in terms of technology intensity.

2 Authors have taken different perspectives regarding the association between IP and OI. While a first perspective considers IP a main antecedent of knowledge sharing and transfer (e.g., Cohen et al., 2000), a second perspective suggests that the firm's innovation strategy (e.g., its openness in innovation) shapes its preferences for IP (Somaya, 2012; James et al., 2013). Recent contributions suggest that there is no unidirectional influence between $\mathrm{OI}$ and IP, since both are strategic choice variables (Laursen and Salter, 2014; Henttonen et al., 2015). 
We investigate these issues in the context of the North American solar industry. ${ }^{3}$ Apart from its economic and policy significance, the solar industry is characterized by an ecosystem of interdependent technologies, products, and services (Overholm, 2014) that is strongly shaped by new entrants (Kapoor and Furr, 2014). This makes it a particularly interesting and suitable empirical setting to examine the following research questions: How does the patent stock of new entrants in a systemic innovation context influence their subsequent OI relationships? And does this association vary by the contents of relationships that are shaped by different degrees of technology intensity?

The remainder of this article is structured as follows: First, we provide some conceptual background on OI. Subsequently, we develop our research hypotheses. Next, we describe our data set, as well as the methods used for empirical analyses. We then report the empirical results, and, finally, we discuss these findings in light of existing literature and draw conclusions and implications for the field of OI as well as some practical implications.

\section{Conceptual background}

OI began as a collection of case studies in a narrow range of industries and in a single geographic region in the United States (Chesbrough, 2003). More recently, however, the literature in OI has expanded in scope and now encompasses many industries and regions (see Chesbrough et al., 2014, for a recent review). Likewise, conceptualizations and definitions of OI have evolved over time, with the most recent definition describing OI "as a distributed innovation process based on purposively managed knowledge flows across organizational boundaries, using pecuniary and non-pecuniary mechanisms in line with the organization's business model" (Chesbrough and Bogers, 2014: 17).

Empirical studies have begun to investigate the prevalence, antecedents, and outcomes of firms' degrees of OI (e.g., Foss et al., 2011; Köhler et al., 2012; Garriga et al., 2013; Roper et al., 2013; Chesbrough and Brunswicker, 2013; Alexy et al., 2016; Lakemond et al., 2016). These empirical studies mainly measure openness in innovation in terms of firms' external search breadth and depth (e.g., Laursen and Salter, 2006; Grimpe and Sofka, 2009; Love et al., 2013). More recently, the relevance of more formal and heterogeneous interorganizational relationships and OI practices has been highlighted (e.g., Laursen and Salter, 2014; Alexy et al., 2016). Especially in the context of systemic innovations, firms are likely to build relationships that vary in content (Adner and Kapoor, 2010). New entrants, in particular, engage in a larger range of different types of interorganizational relationships, as they do not only lack the capacity to rely purely on internal research and development (R\&D) but also need to cooperate for complementary innovation assets (e.g., Christensen et al., 2005). In line with these suggestions, we go beyond general search openness by investigating new entrants' interorganizational relationships. In our analysis, the overall openness in innovation of new entrants is reflected in the number of interorganizational relationships that they engage in.

In addition, we move to a deeper level of analysis to consider the heterogeneity of relationships that new entrants form with external partners. In particular, we suggest that one of the main discriminating factors that distinguishes the underlying content of OI relationships refers to the degree of technology intensity. The degree of technology intensity is a dominant theme in the OI and related literatures. Christensen et al. (2005), for instance, propose that start-ups enter into various OI relationships that mainly differ with respect to the degree to which they are directed toward basic R\&D or the commercialization, distribution, and scaling of technology (see also Hagedoorn, 1993; Du et al., 2014).

Following this research, we suggest that OI relationships can vary from high to low technology intensity. Prior research already proposes that interfirm cooperation is driven by access to a wide range of complementary resources, including those related to science and research (e.g., Hagedoorn, 1993, Christensen, 1995), as well as to marketing and management (e.g., Rothaermel, 2001; Sammarra and Biggiero, 2008). Particularly, prior academic work in the context of innovation networks emphasizes diverse resource exchange across firms (e.g., de Man, 2004; Möller and Rajala, 2007). In a similar vein, but at the firm—rather the network—level of analysis, the notion of OI emphasizes a variety of resources that are being exchanged across organizational boundaries that range from science-based inputs,

3 Due to the industry specificity of patenting (e.g., Pavitt, 1984), a single industry study seemed most appropriate for establishing first empirical evidence for the association between patenting and Ol. While this limits the generalizability of our results to other industries, it also makes a unique contribution to the Ol literature, which, so far, has mainly been characterized by either anecdotal evidence in a specific firm setting (e.g., Chesbrough, 2003; Christensen et al., 2005) or by broad samples, covering a wide range of heterogeneous industries (e.g., Laursen and Salter, 2006, 2014). 
Table 1. Ol relationships of varying degrees of technology intensity

\begin{tabular}{|c|c|c|c|}
\hline $\begin{array}{l}\text { Value Chain } \\
\text { Location }\end{array}$ & $\begin{array}{l}\text { Content of } \\
\text { OI Relationships }\end{array}$ & Types of Complementary Resources and Capabilities Exchanged & Technology Intensity \\
\hline Generation & Scientific Research & $\begin{array}{l}\text { Stored scientific knowledge, joint research, generation of new sci- } \\
\text { entific knowledge }\end{array}$ & High \\
\hline Conversion & Product and Process & $\begin{array}{l}\text { Product development activities, systemic organizational and } \\
\text { managerial assets involved in developing the production } \\
\text { system }\end{array}$ & Medium-high \\
\hline Diffusion & Distribution & $\begin{array}{l}\text { Bundling into marketable solutions, commercial and marketing, } \\
\text { distribution networks }\end{array}$ & Medium-low \\
\hline Implementation & Scale-up & Scale-up experience, infrastructure, regulatory issues & Low \\
\hline
\end{tabular}

product and process development, distribution, to implementation and scaling (e.g., Christensen et al., 2005; Lee et al., 2010; West and Bogers, 2014). For instance, Love et al. (2011) and Ganotikas and Love (2012) have highlighted interdependencies between OI and various stages of the innovation value chain. Along these lines, we suggest that OI relationships include the exchange of heterogeneous resources reflecting the entire innovation value chain, including (i) the generation, (ii) conversion, (iii) diffusion, and (iv) implementation of new technologies (see also Hansen and Birkinshaw, 2007). As a result, we distinguish between four subcategories of OI relationships (see Table 1).

The first category refers to innovation "generation" and entails relationships created for the purpose of scientific research and guided by scientific ethos (see also de Man, 2004; Möller and Rajala, 2007). Resources that are being exchanged in such relationships include existing stock of scientific knowledge as well as new research to add to the existing stock of knowledge (Christensen, 1995; Christensen et al., 2005). Scientific research relationships aim at sourcing and bundling different types of technological knowledge necessary for creating new innovations (Love et al., 2011; Ganotikas and Love, 2012).

Second, the "conversion" aspect of the value chain refers to relationships that deal with more specific product and process innovation. Product and process relationships aim at transforming knowledge, achieving commercially viable business applications, and enhancing the effectiveness of turning evolving ideas and technology into products and processes (Möller and Rajala, 2007; Love et al., 2011). These relationships also deal with resources required to accomplish product development activities, as well as systemic organizational and managerial assets involved in developing the production system (Christensen, 1995; Lee et al., 2010).

The third aspect of the value chain refers to "diffusion" and entails upstream bundling of technological components into marketable solutions, as well as downstream exchange of complementary assets such as marketing and distribution (Teece, 1986; Rothaermel, 2001). As new entrants typically do not have established supply chains and market channels in place, such aspects require innovative activities that enable the diffusion of new technology into the market. Especially in the context of systemic innovation, such bundling and diffusion may not be straightforward, requiring knowledge exchange between value chain partners. New kinds of distribution channels, the disintermediation of existing channels as well the establishment of new channels in nascent and systemic industries are nonobvious and require innovative activities (see also Afuah and Tucci, 2000).

The final part of the value chain refers to "implementation," which secures resources that enable the scaling of new technology. In the context of systemic innovation, the individual product is often not sufficient to scale the solution in the market, as additional collaborative effort is required for addressing infrastructure and regulatory issues. Systemic innovations are often characterized by issues of standardization and complex regulation (Prencipe et al., 2003), which make it more difficult to quickly move a technology to the commercialization stage and which require innovative activities in the overall business model. Therefore, while scale-up relationships are more commercialization oriented, they still involve the exchange of innovation-related knowledge.

We suggest that these categories of relationships can be ordered in terms of decreasing degrees of technology intensity. Resource exchange related to science and the generation of new innovations has, naturally, the highest technology intensity. Product and process innovative assets are still technology intensive but tend to be less abstract and more applied. While diffusion resources can be found in the commercialization group of resources, they still 
include some technological components, such as when firms integrate their components or products to create paths to the market, or in the case of relationships that deal with supplier specifications. Finally, implementation resources are least technology intensive, as innovations and knowledge exchange mainly occur with respect to the business model, rather than the underlying technology, which is already well established. These degrees of technology intensity have important implications for the nature of the underlying relationships and, as we will further elaborate below, shape the association between formal IP and OI.

\section{Hypotheses}

A main argument suggesting that patents are enablers of OI is that formal IP ensures that firms are able to protect and thereby capture value from their innovative activities (Chesbrough, 2006; Pisano and Teece, 2007). More specifically, patenting prevents free-riding behavior of third parties, enables safe knowledge exchanges (e.g., Dubiansky, 2006; Pénin et al., 2011; Ritala and Hurmelinna-Laukkanen, 2013), and allows firms to avoid involuntary knowledge spillovers when they engage with external partners (e.g., Cassimann and Veugelers, 2002; Blind et al., 2006; Lawson et al., 2012; Laursen and Salter, 2014). Throughout the collaboration process, parties conduct some amount of joint work; this is where partner organizations are likely to gain insights into and learn about the new entrant's knowledge base. This increases partner organizations' chances to copy such knowledge, and they may even attempt to appropriate some value from the new entrant's knowledge base, e.g., by filing for new patents themselves. However, as new entrants possess patents related to their knowledge base, partner organizations are more limited in their accumulation of knowledge and skills necessary to conduct imitation activities (e.g., Lawson et al., 2012). Thereby, patents function as isolating mechanisms (Hsu and Ziedonis, 2013) and are important in preventing imitation (Graham et al., 2009; Veer and Jell, 2012). ${ }^{4}$

As firms consider their valuable knowledge to be protected by means of patents, they can be expected to be more likely to enter into OI relationships in which they can share such knowledge under this shield of protection. The initial organization may be willing to share more information that would increase the chances of a successful outcome, if (thanks to receiving an issued patent) it can be confident that this sharing of its knowledge will not compromise its ability to appropriate at least part of the value created. This protection mechanism is particularly important for new entrants who often lack alternative appropriation mechanisms, such as complementary assets, and who are likely to have limited bargaining power in their collaborations with larger organizations. Hence, patents facilitate a balance between knowledge protection and sharing and thereby increase firms' willingness to engage in collaboration (Olander et al., 2010).

Besides their main protective function, patents increase the potential for knowledge sharing in an innovation context through codification (Graham and Mowery, 2006; Pisano and Teece, 2007). Patenting helps firms to disclose all relevant information rather than keeping it secret from potential partners (Anton and Yao, 2004). Furthermore, patent protection suggests that there is relevant knowledge in codified form which makes it easier and more manageable to transfer among partners (Hurmelinna et al., 2007; Olander et al., 2010). The specification of relevant knowledge further facilitates the structuring of the collaborative process (Pénin et al., 2011). This is particularly important in systemic contexts, where the high degree of interdependencies rewards more complete disclosure between parties. As one of the main motivations for entering into OI relationships is the transfer of knowledge and as patents facilitate the disclosure, transfer, and structuring of relevant knowledge, we would expect a positive effect of the patent stock of new entrants on their subsequent OI relationships.

A final mechanism related to the role of patents refers to their signaling function. Formal IP rights can be perceived as signals of innovative capabilities (Cohen et al., 2000; Graham et al., 2009; Hsu and Ziedonis, 2013; Hoenen et al., 2014). In that context, patents can play a role for firms in promoting their internal expertise and thereby drawing attention from potential partners (Alexy et al., 2009; Henttonen et al., 2016), as well as prospective

4 Patents are unlikely to be able to protect all kinds of knowledge inherent in a new entrant's knowledge base. In particular, considering that the patenting process may take a considerable amount of time, some of the newest, most cuttingedge knowledge is less likely to be covered by the new entrant's current patent stock. Provisional patents, however, may provide some level of preliminary protection, and take relatively little time to apply for. This mechanism would allow the technologies in question to be closer to cutting-edge knowledge. However, our empirical analysis is limited to issued patents, not provisional ones. 
Table 2. The strengths of mechanisms across OI relationships of varying degrees of technology intensity

OI Relationships of decreasing technology intensity $\rightarrow$

\begin{tabular}{|c|c|c|c|c|}
\hline Mechanisms & Scientific research & Product and process & Distribution & Scale-up \\
\hline Protection & $\begin{array}{l}\text { High risk of imita- } \\
\text { tion, free riding and } \\
\text { theft of emerging } \\
\text { technology }\end{array}$ & $\begin{array}{l}\text { Risk of misappropriation } \\
\text { remains relatively high } \\
\text { in development of } \\
\text { products and processes }\end{array}$ & $\begin{array}{l}\text { Once a product is created, } \\
\text { alternative protection } \\
\text { mechanisms become } \\
\text { increasingly available }\end{array}$ & $\begin{array}{l}\text { Alternative appropria- } \\
\text { tion mechanisms } \\
\text { often superior to } \\
\text { patenting }\end{array}$ \\
\hline Codification & $\begin{array}{l}\text { Increased structure } \\
\text { and codification } \\
\text { facilitates transfer } \\
\text { of complex techno- } \\
\text { logical knowledge }\end{array}$ & $\begin{array}{l}\text { Decreased complexity of } \\
\text { knowledge- } \\
\text { alternative means of } \\
\text { codification }\end{array}$ & $\begin{array}{l}\text { Information rather than } \\
\text { in-depth knowledge } \\
\text { transfer, which reduces } \\
\text { the need for } \\
\text { codification }\end{array}$ & $\begin{array}{l}\text { Knowledge exchange } \\
\text { related to business } \\
\text { models rather than } \\
\text { technology that } \\
\text { would benefit from } \\
\text { codification }\end{array}$ \\
\hline Signaling & $\begin{array}{l}\text { Patents signal innova- } \\
\text { tive capabilities and } \\
\text { enhance credibility }\end{array}$ & $\begin{array}{l}\text { Patents are complemented } \\
\text { by technological com- } \\
\text { ponents as innovative } \\
\text { signals }\end{array}$ & $\begin{array}{l}\text { Already established tech- } \\
\text { nologies / products } \\
\text { may function as alter- } \\
\text { native signals }\end{array}$ & $\begin{array}{l}\text { Signaling of innova- } \\
\text { tive capabilities } \\
\text { irrelevant }\end{array}$ \\
\hline
\end{tabular}

investors (Graham et al., 2009). ${ }^{5}$ Particularly in the case of new entrants, patents can function as "currency" and substitute for a lack of widespread market recognition (Hertzfeld et al., 2006). New firms can use these patents as "currencies" to influence the initiation and direction of OI relationships. New entrants are particularly likely to use patents to build up exchange potentials and improve their positions in collaborative innovative relationships (Hall and Ziedonis, 2001; Blind et al., 2006). Taken together, the knowledge protection, codification, and signaling functions suggest that:

H1: The patent stock of a new entrant has a positive effect on its overall openness in innovation; i.e., as a new entrant accumulates patents, its subsequent number of new interorganizational relationships increases.

The foregoing hypothesis treats the effects of patents in a uniform way, across all forms of resource exchange. A closer investigation of the contents of different OI relationships might shed more light on the role of formal IP, leading to a more nuanced analysis. In other words, there may exist considerable heterogeneity in the associations between patenting and OI relationships that vary in terms of technology intensity. Table 2 depicts the three identified mechanisms driving $\mathrm{H} 1$ and demonstrates how we expect them to differ across the above conceptualized OI relationships that vary in technology intensity. In the following, we discuss our arguments along Table 2.

If one of the main advantages of patenting is the protection of relevant knowledge, we expect the effect of patent stock on OI to be particularly strong for relationships that are highest in technology intensity-i.e., those that deal with scientific research. The risk of imitation, free-riding and theft is presumably highest when the technology is still under development and when OI partners exchange knowledge relevant for producing and developing new technology. When technological components are still under development, firms are unlikely to have a significant advantage in terms of lead time, thereby increasing the risk of imitation by their partners.

Additionally, given the assumption that patents enable codification and thereby facilitate knowledge sharing in the context of innovation, we would also expect to find a particularly strong and positive effect of patenting on a firm's number of technology-intensive relationships. Technology-intensive relationships are based on concrete research activities, as well as some general endeavor at the technological frontier (Hagedoorn, 1993). Therefore, relationships that deal with the generation of new technology rely on intense knowledge transfer, and the knowledge to

5 Graham et al. (2009) report that the importance of patenting varies across sectors, contrasting the biotech and medical device sectors to those of software and IT, where in the latter sectors patenting was less important in their empirical results. We suggest an alternative interpretation for their empirical findings, which is the degree of technical interdependence is higher in biotech and medical devices, in contrast to software and IT, where technical standards are more established. 
be transferred is typically of high complexity. As a result, the function of patents in terms of codification is particularly valuable in the context of high-technology relationships.

Moreover, along these lines, we expect that the signaling effect, as explained in H1, is likely to be particularly relevant in the context of technology-intensive relationships. If patents represent a signal of innovative capabilities, they should have a particularly strong effect on technology-intensive relationships that focus on joint scientific research. By patenting their inventions, new entrants that are seeking new relationships can increase their credibility and use their patents as bargaining chips in the negotiation of future joint technological development. Similarly, new entrants with proprietary technological knowledge are particularly valuable partners for collaborative research at the technological frontier and are therefore better able to attract partners that are interested in collaborations that generate new technologies.

Conversely, we expect relationships that are of decreasing technology intensity to be gradually less affected by the new entrant's patent stock. While protection by means of patents may still be relevant for relationships that deal with the conversion of innovations into new products, alternative means of protection become increasingly available. Relationships of decreasing technology intensity-i.e., those related to the distribution and scale-up of new technologies-are typically more downstream-oriented and focus on market access, commercialization, and scaling (Hagedoorn, 1993; Hoffman, 2007). The role of patents as a protective mechanism is likely to decrease in importance in such relationships. For instance, in collaborative commercialization, firms can increasingly rely on lead-time, complexity, or secrecy (James et al., 2013), as the nature of the relationship does not require the new entrant to display detailed technological knowledge. The ability to restrict the flow of information in these relationships makes patents as protection devices less important.

As relationships of lower technology intensity are less likely to require in-depth knowledge exchanges, the value of patents in terms of codification is also likely to decrease. As the complexity of knowledge to be transferred decreases, alternative means of codification are likely to be more convenient than lengthy and intricate patent documents. For relationships of low technology intensity that deal with the distribution and scale-up of new technologies, knowledge exchange is mostly related to the underlying business model rather than technology, thereby eliminating the benefits of patents in terms of knowledge codification.

Finally, we also expect the role of signaling to diminish as relationships decrease in technology intensity. The signaling value of patents reduces as information asymmetries decrease (Hoenen et al., 2014) and is less valuable when new entrants have alternative means of signaling their quality (Hsu and Ziedonis, 2013). As technology intensity decreases, firms are likely to have first prototypes or products in place which serve as alternative signals. As the content of relationships shifts to more market-based activities, such as distribution and scale-up, the signaling of innovative capabilities in terms of patents becomes less relevant. In sum, this logic predicts:

H2: The effect of a new entrant's patent stock on its openness in innovation is heterogeneous across relationships of varying degrees of technology intensity, such that it is stronger for technology-intensive relationships and gradually weaker for less technology-intensive relationships.

\section{Methods}

\subsection{Research context}

We investigate our arguments in the context of new entrants in the North American Solar industry during the period of 2007-2013. ${ }^{6}$ This context brings with it a number of advantages that allow us to disentangle the effect of patenting on these firms' OI relationships. First, new entrants are less likely to have established IP strategies in place. While they may strategically use patents as a signaling mechanism to attract external financing (Hsu and Ziedonis, 2013), ${ }^{7}$ various other strategic motives for patenting, such as the offensive and defensive blocking of competitors, are less likely to hold for new entrants (Veer and Jell, 2012). Hence, the broad range of strategic motives for patenting, which

6 We focus on the years 2007-2013 because our primary data source, the Cleantech i3 database, does only partly cover earlier years. All our results hold when we include presumably incomplete data on the years 2005 and 2006.

7 As the strategic use of patenting for signaling purposes is in line with our conceptual model (which predicts that knowledge protection, codification, and signaling explain why patenting leads to more Ol), we do not expect these strategic considerations to distort our results. 
could potentially be shaped by firms' OI strategies, seems less relevant in our empirical context. Second, our archival research design enables us to investigate the consequences of patents that are actually granted. Thereby, it allows us to record what firms actually do, versus what they say in self-reported survey responses, which comprise much of the large sample empirical work published to date in OI.

The solar industry provides an interesting and particularly suitable empirical setting to address our research questions. First, it is an industry that is characterized by systemic technologies that cannot easily be handled by one firm alone (Kapoor and Furr, 2014). As relevant knowledge associated with solar panel production is scattered across various institutions, collaboration by various players is increasingly regarded as an important factor for success. Hence, it is an appropriate empirical setting for investigating the association between patenting and OI in a systemic innovation context. Second, the solar industry is appropriate for studying patenting behavior, due to the recent tremendous rise of patents in that sector. Compared to the average $60 \%$ growth rate in all industries, the growth rate of patenting in solar technology increased by more than $400 \%$ from 1999 to 2008 (Wu and Mathews, 2012). Finally, solar is an emerging industry that is significantly shaped by new entrants (Kapoor and Furr, 2014).

We begin our empirical analysis in the year 2007. This is an appropriate starting point, as the California Solar Initiative, which offers cash back for installing solar on homes and businesses, was launched in that year. ${ }^{8}$ This initiative dramatically changed incentives for solar technologies; thereby changing the market significantly and attracting new entrants (California Public Utilities Commission, 2013). Companies in our data set include mostly photovoltaic firms as well as a small number of solar thermal and lighting companies.

\subsection{Data}

For our empirical analysis, we drew on a proprietary industry database maintained by the Cleantech Group. The Cleantech Group is a leading industry consultant organization for the cleantech sector. It compiles and organizes the i3 platform, which provides data on companies, investors, financing, and relationships across the cleantech ecosystem (e.g., solar, biofuels, wind, etc.). The i3 platform tracks more than 22,000 companies, 5800 investors, and 14,000 relationships. We built our sample in three steps. We started with all North American firms that were active in the solar industry at some point between 2007 and 2013 and were covered by the Cleantech i3 database at the end of 2013. Reflecting our focus on new entrants, we restricted the sample to firms being a maximum of 10 years old at any given time during the sample period (see Graham et al., 2009). ${ }^{9}$ In a second step, data on all relationships that a firm established in a given year were added. The Cleantech Group tracks all publicly announced relationships on the basis of press releases, Web sites, and other publicly available sources. In addition, member firms can own their profile on the i3 platform and submit additional information that is not publicly available. This enables us to capture a larger number of relationships than is typical in databases based on public information. New entrants, in particular, are likely to reveal information regarding their relationships, as they are often looking for investors, for which they might use their relationships as a signaling mechanism. At the same time, they have very little reason to hide information on their relationships, which limits potential reporting biases.

To further increase the validity of our data, we cross-validated these relationships with the Lexis-Nexis database. While a large part of the i3-based relationships could be confirmed, we also noted that the i3 database is less comprehensive for earlier years of our studied time period. Hence, especially for earlier years, we supplemented the relationship data from Cleantech i3 with additional data from Lexis-Nexis. While Lexis-Nexis is incomplete itself as it is based solely on publicly announced relationship, it has been frequently used as a source for identifying relationships in the alliances literature (e.g., Bae and Gargiulo, 2004; Gulati et al., 2009).

8 Due to the concentration of solar business in the state of California, a large number of firms in our data set are based in California and were thereby substantially affected by the California Solar Initiative. To address potential confounding effects of being affected by the California Solar Initiative, we include a dummy variable that marks all firms based in California.

9 All results are robust to changes in the cutoff value of firm age. In unreported regressions, we ran all our estimations again on different samples of firms, where we included also older firms (up to 15 years old). As we found basically the same results, we believe that the chosen cutoff value of 10 years does not impose severe selection effects, but increases comparability of firms within the sample and with regard to other studies that took the same cutoff value (e.g., Graham et al., 2009). 
In a third step, we collected the patents of the sampled firms, starting with all renewable energy patents filed at the US Patent and Trademark Office (USPTO) as identified by Nanda et al. (2014). We matched patents and firms based on the firm name and the assignee name as it appears on each patent document. Due to some misspellings or correct-but-slightly-different name spellings on the patent documents as compared to the firm name in the i3 database, we combined our automatic matching algorithm with an extensive manual review of all matches and additional manual checks of assignee names. For our analysis, we take all USPTO patents into account that had been granted to the firms in the sample through 2012. Finally, we used various databases, such as Hoovers, Crunchbase, and Factiva to collect data on firm exits. We collected information on whether and when start-ups were acquired, went out of business, or filed for bankruptcy. After removing observations with missing values in one or more variables of interest, we arrive at an unbalanced panel data set with 1472 firm-year observations on 346 companies. ${ }^{10}$

\subsection{Variables}

Our hypotheses predict that patent stock is associated with overall openness in innovation in terms of the number of new OI relationships that a new entrant enters, while this association differs across relationships that vary in technology intensity. Hence, we are dealing with a set of dependent variables. Our first dependent variable, openness in innovation, is a count variable measuring the number of all new relationships that a firm enters in a given year. A second set of dependent variables operationalizes the different categories of relationships that we conceptualized above in terms of varying degrees of technology intensity. ${ }^{11}$ Based on a careful industry analysis, we developed a coding scheme that would allow us to classify relationships described in our data set. Our coding scheme is displayed in Table 3, including definitions and keywords, as well as examples of the identified relationships.

Scientific research relationships is a count variable of the number of new relationships that a new entrant enters in a given year, which focuses on the generation of new solar technologies, innovating the main components of solar panels (such as base materials, ingot, wafers, solar cells), as well as technology-intensive complements that refer to "balance-of-system" solutions (technologies that are essential for converting, storing, and distributing solar energy). Product and process relationships is a count variable of the number of new relationships that a firm enters each year, which deals with the conversion of new technologies into products and processes, i.e., the conversion of new cell technologies into solar panels. Such relationships also focus on complementary assets and services, including demonstration and testing, increasing the compatibility of components and modules, software programs for energy distribution, as well as standard setting. Distribution relationships is a count variable of the number of new relationships that a firm enters each year that focus on distribution, internationalization, and marketing of solar panels and related products. Finally, scale-up relationships deals with the construction and implementation of solar facilities, plants, arrays, or structures that involve the production of power. They focus on infrastructure and regulatory issues as well as on integrating all elements that are required for the actual installation of solar structures. One example of a collaborative innovative activity in the solar industry with respect to scaling refers to the "Power Purchasing Agreement," which presented a new contractual way among multiple parties to set up solar services.

In our empirical analysis, we consider the following independent and control variables. Our main independent variable, patent stock, refers to the number of patents granted to a specific new entrant up to year $t-1$. Our empirical context makes it difficult to collect a large number of control variables, as data are often unavailable for new entrants. We include firm age as well the age squared, reflecting the assumption of increasing numbers of relationships over time, but with decreasing magnitude (e.g., Carroll and Hannan, 1989). ${ }^{12}$ As a proxy for the size of the new entrant, we include the cumulative number of customers that firms have gained up to a given year. In order to proxy for the quality of the new entrants, which could influence their ability to patent as well as their ability to attract OI partners, we include a dummy variable that indicates whether firms have ever been elected into the "Cleantech 100" group. The "Cleantech 100" is a list of the top 100 private companies in clean technology that is elected yearly by the Cleantech Group based on industry research, nominations, and evaluation of an expert panel.

10 The reduction from the initial set of firms covered by Cleantech i3 was mainly due to some firms for which we could not determine the founding year.

11 The construction of our set of dependent variables entails the assumption that all Ol relationships, irrespective of partner type and partner size, are of equal importance.

12 In alternative specifications, we took only the linear term as a control for age or log (age). All those models lead to qualitatively the same results, but the ones with age and age squared showed the best model fit. 
Table 3. Definitions and coding scheme of different categories of relationships

\begin{tabular}{|c|c|c|c|}
\hline $\begin{array}{l}\text { OI relationship } \\
\text { categories }\end{array}$ & Definition & Exemplary key words & Examples \\
\hline $\begin{array}{l}\text { Scientific research } \\
\text { relationships }\end{array}$ & $\begin{array}{l}\text { Relationships that focus on joint } \\
\text { research and technology devel- } \\
\text { opment at the technological } \\
\text { frontier }\end{array}$ & $\begin{array}{l}\text { Technology development, tech- } \\
\text { nology transfer, joint R\&D }\end{array}$ & $\begin{array}{l}1366 \text { Technologies will collaborate with } \\
\text { Tokuyama on the R\&D of } 1366 \\
\text { Technologies' Direct Wafer } \\
\text { technology. } \\
\text { Solarmer Energy, The US Department of } \\
\text { Energy's, and the National Renewable } \\
\text { Energy Laboratory have signed a } \\
\text { cooperative research and development } \\
\text { agreement to collaborate on improv- } \\
\text { ing the lifetime of plastic solar cells, a } \\
\text { new solar conversion technology. }\end{array}$ \\
\hline $\begin{array}{l}\text { Product and } \\
\text { process } \\
\text { relationships }\end{array}$ & $\begin{array}{l}\text { Relationships that focus on the } \\
\text { development of a specific } \\
\text { product, including all develop- } \\
\text { ment-oriented complements } \\
\text { and services attached to that } \\
\text { product. }\end{array}$ & $\begin{array}{l}\text { Demonstration and testing, man- } \\
\text { ufacturing, module develop- } \\
\text { ment, compatibility and } \\
\text { services, standard setting }\end{array}$ & $\begin{array}{l}\text { juwi and ArrayPower partnered to test } \\
\text { ArrayPower's sequenced inverter in } \\
\text { the field. } \\
\text { Solar Enertech is working with AQT as a } \\
\text { module manufacturing partner for } \\
\text { AQT's copper indium gallium selenide } \\
\text { solar cells and assists with product } \\
\text { certification. }\end{array}$ \\
\hline $\begin{array}{l}\text { Distribution } \\
\quad \text { relationships }\end{array}$ & $\begin{array}{l}\text { Relationships that focus on the } \\
\text { upstream and downstream } \\
\text { channels related to the distri- } \\
\text { bution of marketable solu- } \\
\text { tions, as well as the } \\
\text { internationalization and mar- } \\
\text { keting of these solutions }\end{array}$ & $\begin{array}{l}\text { Supplier relationship, distribu- } \\
\text { tion, reseller, internationaliza- } \\
\text { tion, marketing or commercial }\end{array}$ & $\begin{array}{l}\text { Enphase will provide micro-inverters for } \\
\text { Broosha to bundle with photovoltaic } \\
\text { modules and customer support. } \\
\text { Air Liquide and Sixtron Advanced } \\
\text { Materials have announced partnership } \\
\text { to promote and distribute advanced } \\
\text { coating materials to crystalline silicon } \\
\text { (c-Si) solar cell manufacturers } \\
\text { worldwide. }\end{array}$ \\
\hline $\begin{array}{l}\text { Scale-up } \\
\quad \text { relationships }\end{array}$ & $\begin{array}{l}\text { Relationships that focus on the } \\
\text { scaling of a firm's product or } \\
\text { solution. These relationships } \\
\text { are associated with the physi- } \\
\text { cal construction of solar facili- } \\
\text { ties and the production of } \\
\text { watt. }\end{array}$ & $\begin{array}{l}\text { Solar power facility/plants, joint } \\
\text { installations of photovoltaic } \\
\text { systems and arrays }\end{array}$ & $\begin{array}{l}\text { First Solar and Verve Energy have begun } \\
\text { building Australia's first utility-scale } \\
\text { solar power project. } \\
\text { Sopogy has signed an agreement with } \\
\text { Inypsa and Omniwatt. The agreement } \\
\text { is for the development of } 50 \text { megawatt } \\
\text { solar power plant by December } 1 \text {, } \\
2010 \text { in Toledo, Spain }\end{array}$ \\
\hline
\end{tabular}

Given the heterogeneity of firms in our sample, we also control for different types of new entrants that address different parts of the solar ecosystem. Firms' positions in the solar ecosystem can be mainly categorized into upstream "material providers" (firms that produce silicon, thin-film technology, ingots, wafers, or manufacturing equipment), midstream "cell manufacturers"(manufacturers of solar cells and modules), downstream "balance of system" providers (inverters, energy management systems, tracking technology, structures, arrays, mounting, etc.), and downstream "solar system integrators" (designers, distributors, installers, and managers of residential and commercial solar systems). We used "cell manufacturers" as our baseline and included dummy variables for the remaining categories. Furthermore, as the solar industry is characterized by competing underlying technological trajectories, we also create dummy variables to capture whether firms base their technologies on "silicon," "thin-film," or "other technologies," such as organic technologies or concentrated solar. These trajectories differ with respect to their technological maturity and with respect to the availability of complementary assets (Kapoor and Furr, 2014) and may 
Table 4. Variables used in this study

\begin{tabular}{|c|c|c|}
\hline Variable & Description & Source \\
\hline Age & Years since the company has been founded & $\begin{array}{l}\text { Cleantech i3, Company } \\
\text { Reports }\end{array}$ \\
\hline Patent stock & Number of granted patents up to year $t-1$ & USPTO, Nanda et al., 2014 \\
\hline $\begin{array}{l}\text { Openness in } \\
\text { Innovation }\end{array}$ & $\begin{array}{l}\text { Count variable of the number of all new relationships that a firm } \\
\text { enters in } t\end{array}$ & Cleantech i3, LexisNexis \\
\hline $\begin{array}{l}\text { Scientific Research } \\
\text { Relationships }\end{array}$ & $\begin{array}{l}\text { Count variable of the number of new scientific research relationships } \\
\text { that a firm enters in } t\end{array}$ & Cleantech i3, LexisNexis \\
\hline $\begin{array}{l}\text { Product and } \\
\text { Process } \\
\text { Relationships }\end{array}$ & $\begin{array}{l}\text { Count variable of the number of new product and process relation- } \\
\text { ships that a firm enters in } t\end{array}$ & Cleantech i3, LexisNexis \\
\hline $\begin{array}{l}\text { Distribution } \\
\text { Relationships }\end{array}$ & $\begin{array}{l}\text { Count variable of the number of new distribution relationships that a } \\
\text { firm enters in } t\end{array}$ & Cleantech i3, LexisNexis \\
\hline $\begin{array}{l}\text { Scale-up } \\
\text { Relationships }\end{array}$ & $\begin{array}{l}\text { Count variable of the number of new scale-up relationships that a firm } \\
\text { enters in } t\end{array}$ & Cleantech i3, LexisNexis \\
\hline Customers & $\begin{array}{l}\text { Count variable of the cumulative number of customers that a firm } \\
\text { reached up to year } t\end{array}$ & Cleantech i3, LexisNexis \\
\hline Cleantech 100 & $\begin{array}{l}\text { Dummy variable indicating whether the firm has been mentioned as a } \\
\text { top } 100 \text { cleantech company }\end{array}$ & Cleantech i3 \\
\hline Thin-film & $\begin{array}{l}\text { Dummy variable indicating whether the firm's main technology is } \\
\text { thin-film solar cells }\end{array}$ & $\begin{array}{l}\text { Cleantech i3, manual } \\
\text { coding }\end{array}$ \\
\hline $\begin{array}{l}\text { Other } \\
\text { technologies }\end{array}$ & $\begin{array}{l}\text { Dummy variable indicating whether the firm's main technology is } \\
\text { other than thin-film or silicon solar cells }\end{array}$ & $\begin{array}{l}\text { Cleantech i3, manual } \\
\text { coding }\end{array}$ \\
\hline Massachusetts & $\begin{array}{l}\text { Dummy variable indicating whether the firm is situated in } \\
\text { Massachusetts }\end{array}$ & Cleantech i3 \\
\hline California & Dummy variable indicating whether the firm is situated in California & Cleantech i3 \\
\hline $\begin{array}{l}\text { Material } \\
\text { providers }\end{array}$ & $\begin{array}{l}\text { Dummy variable indicating whether the firm produces silicon, } \\
\text { thin-film technology, ingots, wafers, or manufacturing equipment }\end{array}$ & $\begin{array}{l}\text { Cleantech i3, manual } \\
\text { coding }\end{array}$ \\
\hline Balance of system & $\begin{array}{l}\text { Dummy variable indicating whether firm produces inverters, energy } \\
\text { management systems, tracking technology, structures, arrays, or } \\
\text { mounting }\end{array}$ & $\begin{array}{l}\text { Cleantech i3, manual } \\
\text { coding }\end{array}$ \\
\hline Integrators & $\begin{array}{l}\text { Dummy variable indicating whether firm designs, distributes, installs, } \\
\text { or manages residential and commercial solar systems }\end{array}$ & $\begin{array}{l}\text { Cleantech i3, manual } \\
\text { coding }\end{array}$ \\
\hline
\end{tabular}

Note: This table reports variable definitions and data sources.

therefore have an influence on what types of relationships firms enter. As silicon constitutes the traditional, most established technological trajectory, we take "silicon" as our baseline. In order to capture geographical advantages of being located in the main "hot spots" for solar technology, we created two dummy variables indicating whether firms are based in "California" or "Massachusetts." Finally, we include a full set of year dummies in our analysis to control for unobserved changes in the solar industry across time. Table 4 provides an overview of these variables.

\section{Analysis and results}

Table 5 provides descriptive statistics for the pooled data. The firms in our sample are on average 4.1 years old, with a median age of 4 years and a standard deviation of 2.42 years. While the distribution of firm age in the sample is only moderately skewed toward younger firms, the number of granted patents and the number of relationships that a given firm establishes in a given year are highly left skewed. Most firms in our sample establish no relationships in a given year and those that do enter into new relationships typically establish only one new relationship per year. At the same time, over the whole sampling period, $34 \%$ of the firms have established at least one relationship during 2007 and 2013, and we observe firms with up to 10 new relationships founded in a given year.

As Figure 1 illustrates, engagement in new relationships increases substantially with firm age. A similar pattern can be observed with regard to patenting. The distribution is highly skewed toward only a few new entrants that 


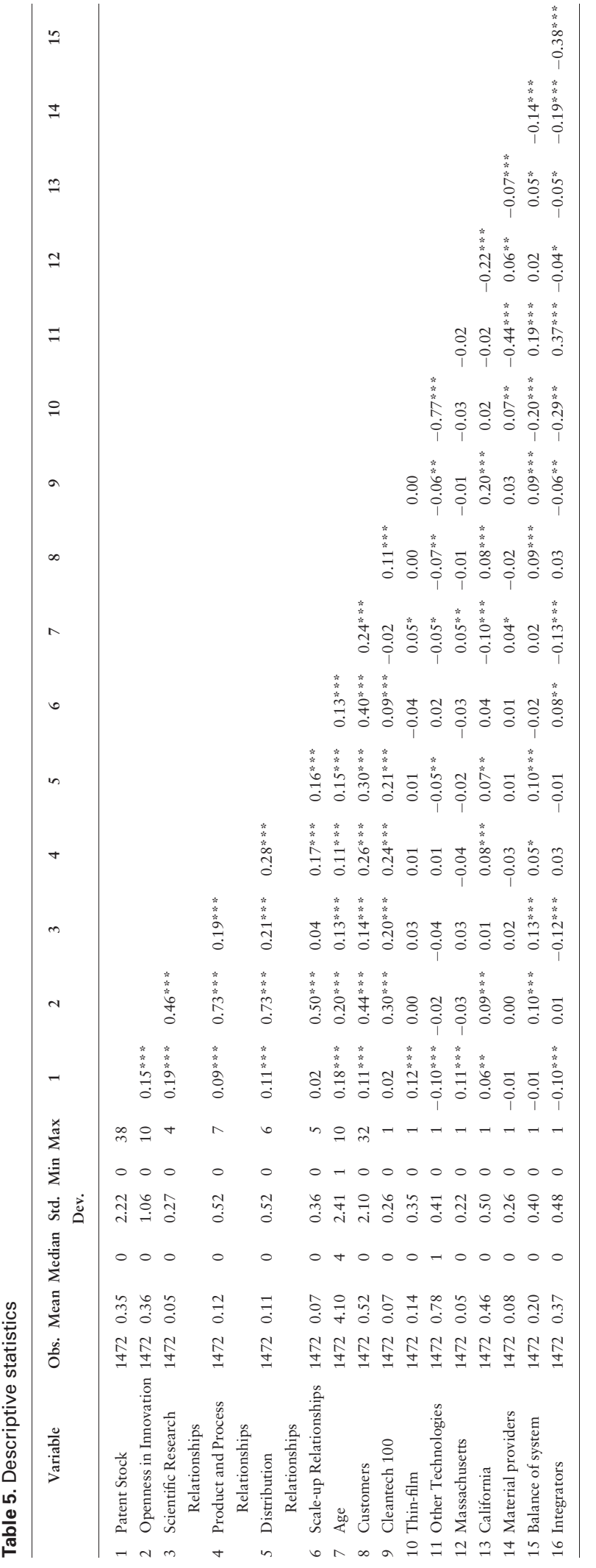




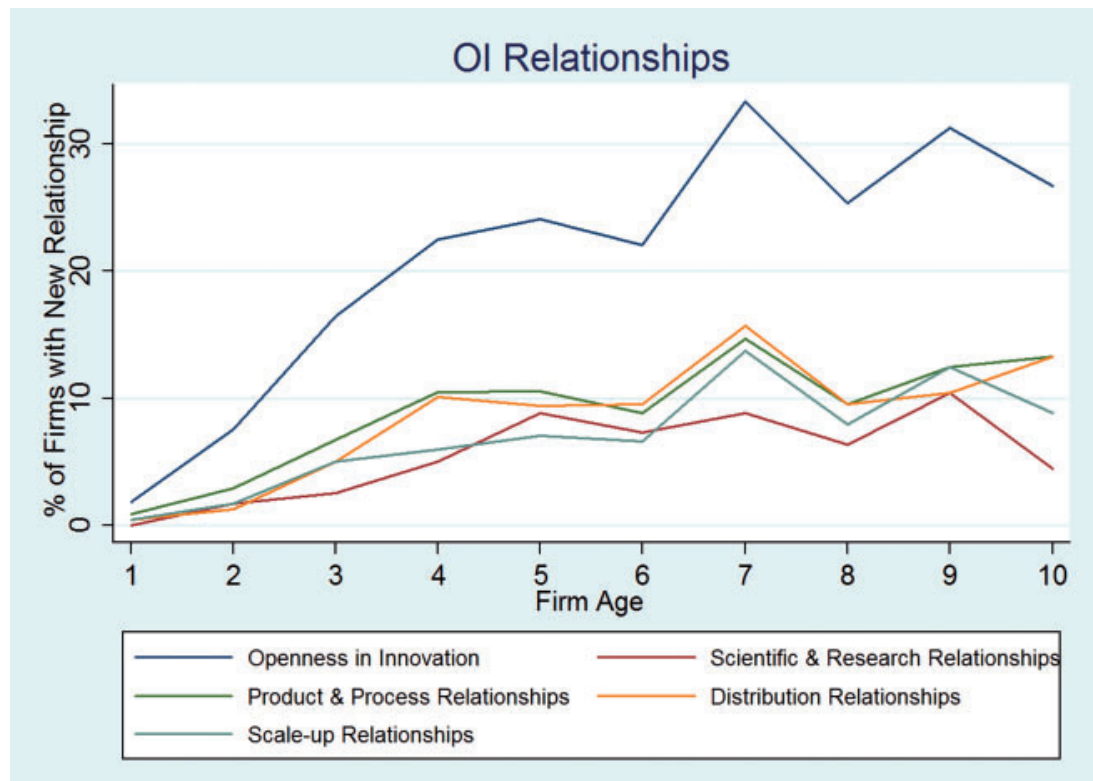

Figure 1. Percentage of firms with new relationships at a given age.

patent, but the proportion of firms that have at least one patent granted increases substantially with growing firm age. Overall, Figures 1 and 2 suggest that OI relationships, as well as patenting, become increasingly important for new entrants during their first years in the solar market.

All proxies of OI relationships have the common feature of being nonnegative integer variables. Poisson models that account for this specific type of data are thus our preferred regression technique. ${ }^{13}$ In order to reduce potential simultaneity issues, we take the stock of patents granted up to year $t-1$ as our main regressor. In order to account for diminishing values of patents over time, we apply a standard perpetual inventory equation. Specifically, we calculate the current value of the patent stock $P S_{t}$ as:

$$
P S_{t}=(1-\delta) \cdot P_{t-1}=P_{t},
$$

where $P_{t}$ is the number patents granted during the year. Following the literature (see e.g., Griliches and Mairesse, 1984; Hall, 1990; or Czarnitzki and Toole, 2011, for details), the knowledge depreciation rate $\delta$ is chosen to be $15 \% .{ }^{14}$ Given the reported skewness of the number of patents, all estimations are run with the logarithm of the patent stock $(+1)$. In all specifications, we include our set of control variables, as well as six time dummies to account for potential confounding effects of unobserved changes in the business environment across years. The computed standard errors appear to be robust to heteroscedasticity and account for repeated observations at the firm level.

Table 6 shows the results of our five baseline specifications. Model $a$ is a regression of openness in innovation, thereby capturing the total number of new relationships on the number of patents granted up to year $t-1$. Models $b-e$ represent our categories of relationships that vary in terms of technology intensity. ${ }^{15}$ Regarding our hypotheses,

13 Poisson models are consistent even in case of a violation of the underlying distributional assumption, whereas negative binomial models are generally more efficient but prone to specification error if distributional assumptions are not met. In alternative regressions, we confirmed that our results are robust to estimating negative binomial models.

14 All results reported below are robust to choosing no depreciation rate or a higher rate of $30 \%$ instead of $15 \%$. For a similar approach in a different context, see also King and Tucci (2002).

15 As the decision to enter a certain kind of relationship might be dependent also on the decision to enter another kind of relationship, we check for a seemingly unrelated Poisson model of the kind developed by Zellner and Huang (1962) for OLS. However, to the best of the authors' knowledge, such a model is not available. We therefore manually checked 


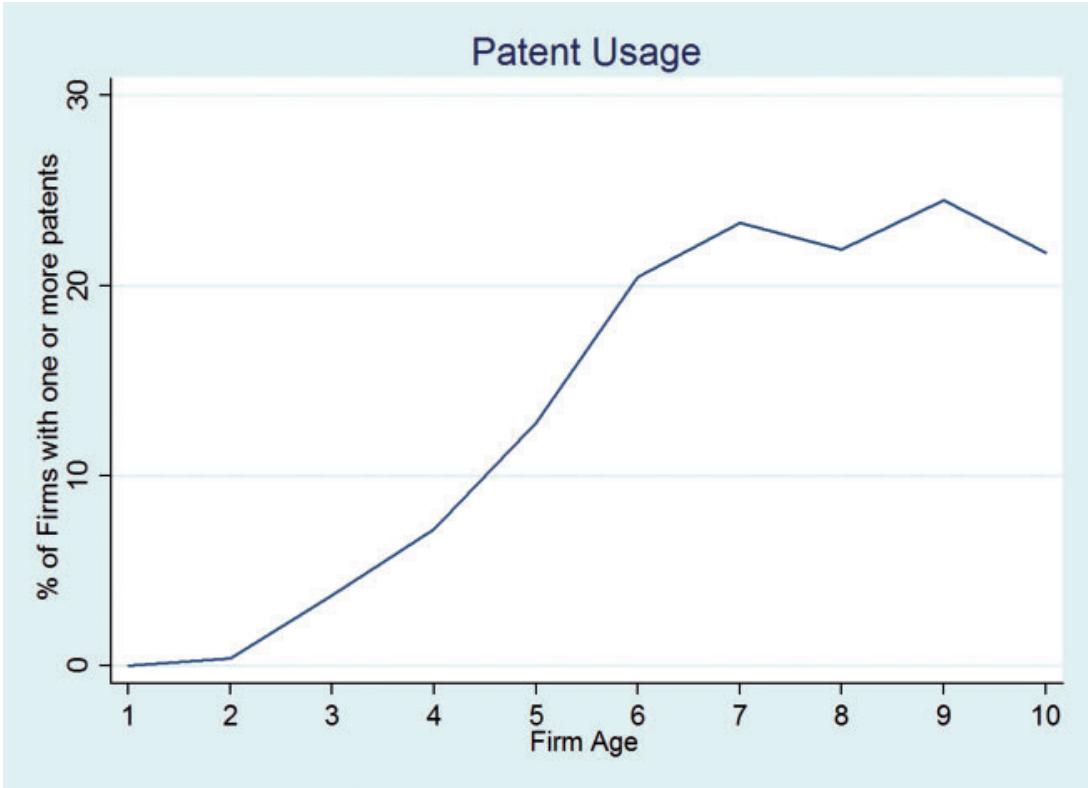

Figure 2. Percentage of firms with a positive stock of granted patents at a given age.

the results suggest that a new entrant's openness in innovation, i.e., the overall number of relationships in year $t$, increases with its patent stock in year $t-1$. The coefficient of patent stock is positive $(0.403)$ and significant $(P<0.05)$. These results provide support for $\mathrm{H} 1$.

In order to draw inferences with respect to the second hypothesis, we compare coefficients across the different relationship categories. The magnitude and level of significance of the coefficient of patent stock is greatest for scientific research relationships $(0.945 ; P<0.01)$. The magnitude of the coefficient of patent stock is lower for product and process relationships $(0.542 ; P<0.01)$ and distribution relationships $(0.549 ; P<0.05)$, although the difference between the latter two coefficients is not substantial. Finally, the coefficient of patent stock is considerably lower and significantly negative for scale-up relationships $(-0.771 ; P<0.1)$. A comparison of these coefficients provides some understanding of the relative importance of patents for entering into different relationship categories. The effect is relatively more important for technology-intensive relationships and is even significantly negative for scale-up relationships (which we assume to have the lowest technology intensity). ${ }^{16}$ Hence, the results provide support for $\mathrm{H} 2$.

Regarding our set of control variables, the results from the baseline models suggest that the overall openness in innovation in terms of the number of new relationships increases with firm age, while this effect diminishes over time as indicated by a negative coefficient of the squared term. In terms of technological trajectories, new entrants that focus on thin-film enter more scientific research as well as product and process relationships. This corresponds to the

the pairwise correlations of the residuals of all models. As the correlations are small, ranging between -0.03 and 0.17 , we believe that our results are not biased. Further, seemingly unrelated regressions primarily affect the efficiency of the estimation, leaving the coefficient estimates largely unchanged, especially when correlations of residuals are low, as it is the case with our analysis. The computed standard errors in our models are thus likely to be overestimated and thus provide rather conservative estimates.

16 A Chi-square test on equality of the log (Patent Stock) coefficients in specifications b-d of Table 6 reveals statistically significant differences (Chi-square value: $13.03, P$-value: $<0.005$ ). Two-sided tests of pairwise differences are often not statistically significant. This is either because the coefficient sizes are indeed close to each other, for instance, in the case of Product and Process Relationships compared to Distribution Relationships, or because our sample size is too small to allow a precise enough estimation. 
Table 6. Poisson regressions—relationships and patenting

\begin{tabular}{|c|c|c|c|c|c|}
\hline Dependent variable: & $\begin{array}{l}\text { a } \\
\text { Openness in } \\
\text { Innovation }\end{array}$ & $\begin{array}{l}\quad \text { b } \\
\text { Scientific Research } \\
\text { Relationships }\end{array}$ & $\begin{array}{l}\quad \mathrm{c} \\
\text { Product and Process } \\
\text { Relationships }\end{array}$ & \begin{tabular}{l}
\multicolumn{1}{c}{$\mathrm{d}$} \\
Distribution \\
Relationships
\end{tabular} & $\begin{array}{l}\quad \text { e } \\
\text { Scale-up } \\
\text { Relationships }\end{array}$ \\
\hline Age & $\begin{array}{l}0.764 * * * \\
(0.118)\end{array}$ & $\begin{array}{l}1.133 * * * \\
(0.240)\end{array}$ & $\begin{array}{l}0.770 * * * \\
(0.162)\end{array}$ & $\begin{array}{l}0.910 * * * \\
(0.237)\end{array}$ & $\begin{array}{l}0.428 * * \\
(0.195)\end{array}$ \\
\hline Age sq. & $\begin{array}{c}-0.052 * * * \\
(0.011)\end{array}$ & $\begin{array}{l}-0.084^{* * * *} \\
(0.020)\end{array}$ & $\begin{array}{l}-0.055 * * \\
(0.015)\end{array}$ & $\begin{array}{l}-0.058 * * * \\
(0.021)\end{array}$ & $\begin{array}{c}-0.032 * \\
(0.017)\end{array}$ \\
\hline Thin-film & $\begin{array}{c}0.321 \\
(0.300)\end{array}$ & $\begin{array}{l}0.978 * * \\
(0.485)\end{array}$ & $\begin{array}{c}1.082 \% \\
(0.583)\end{array}$ & $\begin{array}{r}-0.075 \\
(0.430)\end{array}$ & $\begin{array}{r}-0.004 \\
(0.659)\end{array}$ \\
\hline Other Technologies & $\begin{array}{c}0.371 * \\
(0.224)\end{array}$ & $\begin{array}{l}0.842 * \\
(0.506)\end{array}$ & $\begin{array}{l}1.112^{* *} \\
(0.493)\end{array}$ & $\begin{array}{r}-0.461 \\
(0.305)\end{array}$ & $\begin{array}{l}0.713 * * \\
(0.318)\end{array}$ \\
\hline Cleantech 100 & $\begin{array}{l}1.331 * * * \\
(0.163)\end{array}$ & $\begin{array}{l}1.690 * * * \\
(0.281)\end{array}$ & $\begin{array}{l}1.562 * * * \\
(0.259)\end{array}$ & $\begin{array}{l}1.407 * * * \\
(0.275)\end{array}$ & $\begin{array}{c}0.684 * \\
(0.381)\end{array}$ \\
\hline Massachusetts & $\begin{array}{r}-0.339 \\
(0.311)\end{array}$ & $\begin{array}{c}0.253 \\
(0.421)\end{array}$ & $\begin{array}{r}-0.953 \\
(0.690)\end{array}$ & $\begin{array}{r}-0.165 \\
(0.419)\end{array}$ & $\begin{array}{r}-1.177^{*} \\
(0.649)\end{array}$ \\
\hline California & $\begin{array}{r}-0.014 \\
(0.140)\end{array}$ & $\begin{array}{c}-0.482 * \\
(0.275)\end{array}$ & $\begin{array}{c}0.045 \\
(0.238)\end{array}$ & $\begin{array}{c}0.135 \\
(0.248)\end{array}$ & $\begin{array}{c}0.123 \\
(0.255)\end{array}$ \\
\hline $\log$ (Customers) & $\begin{array}{l}0.737^{* * *} \\
(0.090)\end{array}$ & $\begin{array}{l}0.492 * * \\
(0.193)\end{array}$ & $\begin{array}{l}0.577^{* * *} \\
(0.139)\end{array}$ & $\begin{array}{l}0.570 * * * \\
(0.154)\end{array}$ & $\begin{array}{l}1.408 * * * \\
(0.123)\end{array}$ \\
\hline Material providers & $\begin{array}{c}0.490 * \\
(0.297)\end{array}$ & $\begin{array}{c}0.638 \\
(0.516)\end{array}$ & $\begin{array}{c}0.349 \\
(0.474)\end{array}$ & $\begin{array}{c}0.488 \\
(0.455)\end{array}$ & $\begin{array}{c}0.531 \\
(0.435)\end{array}$ \\
\hline Balance of system & $\begin{array}{l}0.389 * * \\
(0.187)\end{array}$ & $\begin{array}{l}0.632 * * \\
(0.310)\end{array}$ & $\begin{array}{c}0.368 \\
(0.269)\end{array}$ & $\begin{array}{l}0.973 * * \\
(0.385)\end{array}$ & $\begin{array}{c}-0.699 * \\
(0.398)\end{array}$ \\
\hline Integrators & $\begin{array}{c}0.342 * \\
(0.186)\end{array}$ & $\begin{array}{l}-1.591 * * * \\
(0.460)\end{array}$ & $\begin{array}{l}0.543 * * \\
(0.267)\end{array}$ & $\begin{array}{c}0.753 * \\
(0.398)\end{array}$ & $\begin{array}{c}0.319 \\
(0.300)\end{array}$ \\
\hline Log (Patent stock) & $\begin{array}{l}0.403 * * \\
(0.192)\end{array}$ & $\begin{array}{l}0.945 * * * \\
(0.239)\end{array}$ & $\begin{array}{l}0.542 * * \\
(0.227)\end{array}$ & $\begin{array}{l}0.549 * * \\
(0.266)\end{array}$ & $\begin{array}{c}-0.771 \% \\
(0.398)\end{array}$ \\
\hline Time fixed effects & yes & yes & yes & yes & yes \\
\hline$N$ & 1472 & 1472 & 1472 & 1472 & 1472 \\
\hline Pseudo $R^{2}$ & 0.317 & 0.278 & 0.250 & 0.279 & 0.293 \\
\hline
\end{tabular}

Note: The table reports the results from Poisson regressions of the number of different categories of relationships. Coefficients: ***Significant at $1 \%$, * Significant at $5 \%,{ }^{*}$ Significant at $10 \%$ level. Robust standard errors reported in parentheses. Log (Patent stock +1 ) is lagged by one period. Details on variable definitions and data sources are provided in Table 1.

fact that thin-film is in an earlier stage of technological development in comparison to silicon. As expected, highquality firms—as proxied by their "Cleantech 100" membership—enter significantly more OI relationships. The new entrant's location only plays a marginal role-surprisingly, being located in California has a marginally negative effect on scientific research relationships, while firms located in Massachusetts enter into significantly fewer scale-up relationships. Our proxy for firm size-the number of new customers each year-has a significantly positive effect across all relationship categories. The position of new entrants in the solar ecosystem reveals an interesting pattern. As compared to cell manufacturers, materials providers, balance-of-system firms as well as integrators, in general, tend to enter more OI relationships. Regarding specific categories of relationships, balance-of-system firms enter more scientific research and distribution relationships and fewer scale-up relationships. As expected, integrators enter significantly less scientific research relationships, but more product and process and distribution relationships, as compared to cell manufacturers.

\subsection{Addressing potential selection biases}

Systematic differences of new entrants that patent as compared to those that do not patent may be correlated with the propensity to enter new relationships. In such a case, our patent coefficient estimations might be up- or downward-biased. In order to assess whether these potential biases in our regressions are of major concern, we run a placebo test. This test is based on the notion that if patenting firms are indeed systematically different to 
Table 7. Placebo test

\begin{tabular}{|c|c|c|c|c|c|}
\hline Dependent variable: & $\begin{array}{c}\text { a } \\
\text { Openness in } \\
\text { Innovation }\end{array}$ & $\begin{array}{c}\text { b } \\
\text { Scientific Research } \\
\text { Relationships }\end{array}$ & $\begin{array}{c}\text { C } \\
\text { Product and Process } \\
\text { Relationships }\end{array}$ & $\begin{array}{c}\text { d } \\
\text { Distribution } \\
\text { Relationships }\end{array}$ & $\begin{array}{c}\text { e } \\
\text { Scale-up } \\
\text { Relationships }\end{array}$ \\
\hline Age & $\begin{array}{l}0.767^{* * *} \\
(0.121)\end{array}$ & $\begin{array}{l}1.119 * * * \\
(0.236)\end{array}$ & $\begin{array}{l}0.756^{* * * *} \\
(0.166)\end{array}$ & $\begin{array}{l}0.923 * * * \\
(0.241)\end{array}$ & $\begin{array}{l}0.449 * * \\
(0.197)\end{array}$ \\
\hline Age sq. & $\begin{array}{l}-0.052 * * * \\
(0.011)\end{array}$ & $\begin{array}{l}-0.082 * * * \\
(0.020)\end{array}$ & $\begin{array}{l}-0.054 * * * \\
(0.015)\end{array}$ & $\begin{array}{l}-0.060 * * * \\
(0.022)\end{array}$ & $\begin{array}{c}-0.034 * \\
(0.018)\end{array}$ \\
\hline Thin-film & $\begin{array}{l}1.342 * * * \\
(0.180)\end{array}$ & $\begin{array}{l}1.658 * * * \\
(0.284)\end{array}$ & $\begin{array}{l}1.528 * * * \\
(0.293)\end{array}$ & $\begin{array}{l}1.483^{* * * *} \\
(0.295)\end{array}$ & $\begin{array}{l}0.819 * \\
(0.326)\end{array}$ \\
\hline Other Technologies & $\begin{array}{c}0.322 \\
(0.300)\end{array}$ & $\begin{array}{l}0.984 * * \\
(0.474)\end{array}$ & $\begin{array}{l}1.084 * \\
(0.584)\end{array}$ & $\begin{array}{r}-0.076 \\
(0.430)\end{array}$ & $\begin{array}{c}0.048 \\
(0.639)\end{array}$ \\
\hline Cleantech 100 & $\begin{array}{c}0.373 * \\
(0.223)\end{array}$ & $\begin{array}{c}0.842 * \\
(0.480)\end{array}$ & $\begin{array}{l}1.108 * * \\
(0.489)\end{array}$ & $\begin{array}{r}-0.460 \\
(0.302)\end{array}$ & $\begin{array}{l}0.762 * * \\
(0.342)\end{array}$ \\
\hline Massachusetts & $\begin{array}{r}-0.337 \\
(0.311)\end{array}$ & $\begin{array}{c}0.198 \\
(0.436)\end{array}$ & $\begin{array}{r}-0.966 \\
(0.686)\end{array}$ & $\begin{array}{r}-0.155 \\
(0.422)\end{array}$ & $\begin{array}{c}-1.193 * \\
(0.646)\end{array}$ \\
\hline California & $\begin{array}{r}-0.013 \\
(0.141)\end{array}$ & $\begin{array}{c}-0.504 * \\
(0.278)\end{array}$ & $\begin{array}{c}0.036 \\
(0.244)\end{array}$ & $\begin{array}{c}0.125 \\
(0.244)\end{array}$ & $\begin{array}{c}0.130 \\
(0.254)\end{array}$ \\
\hline Log (Customers) & $\begin{array}{c}0.487 \\
(0.298)\end{array}$ & $\begin{array}{c}0.653 \\
(0.507)\end{array}$ & $\begin{array}{c}0.356 \\
(0.470)\end{array}$ & $\begin{array}{c}0.455 \\
(0.460)\end{array}$ & $\begin{array}{c}0.536 \\
(0.442)\end{array}$ \\
\hline Material providers & $\begin{array}{l}0.390 * * \\
(0.187)\end{array}$ & $\begin{array}{l}0.625 * * \\
(0.309)\end{array}$ & $\begin{array}{c}0.371 \\
(0.269)\end{array}$ & $\begin{array}{l}0.983 * * \\
(0.388)\end{array}$ & $\begin{array}{r}-0.682 * \\
(0.405)\end{array}$ \\
\hline Balance of system & $\begin{array}{c}0.338 * \\
(0.183)\end{array}$ & $\begin{array}{l}-1.562 * * * \\
(0.457)\end{array}$ & $\begin{array}{l}0.555 * * \\
(0.259)\end{array}$ & $\begin{array}{c}0.737^{*} \\
(0.400)\end{array}$ & $\begin{array}{c}0.296 \\
(0.296)\end{array}$ \\
\hline Integrators & $\begin{array}{l}0.739 * * * \\
(0.089)\end{array}$ & $\begin{array}{l}0.467 * * \\
(0.186)\end{array}$ & $\begin{array}{l}0.567 * * * \\
(0.133)\end{array}$ & $\begin{array}{l}0.587 * * * \\
(0.157)\end{array}$ & $\begin{array}{l}1.428 * * * \\
(0.130)\end{array}$ \\
\hline Log (Patent stock) & $\begin{array}{c}0.395 \% \\
(0.204)\end{array}$ & $\begin{array}{l}0.981 * * * \\
(0.232)\end{array}$ & $\begin{array}{l}0.569 * * \\
(0.229)\end{array}$ & $\begin{array}{c}0.501 * \\
(0.294)\end{array}$ & $\begin{array}{c}-0.866 * * \\
(0.396)\end{array}$ \\
\hline Pre-patenting & $\begin{array}{r}-0.045 \\
(0.215)\end{array}$ & $\begin{array}{c}0.278 \\
(0.353)\end{array}$ & $\begin{array}{c}0.141 \\
(0.345)\end{array}$ & $\begin{array}{r}-0.312 \\
(0.333)\end{array}$ & $\begin{array}{r}-0.343 \\
(0.474)\end{array}$ \\
\hline Time fixed effects & yes & yes & yes & yes & yes \\
\hline$N$ & 1472 & 1472 & 1472 & 1472 & 1472 \\
\hline Pseudo $R^{2}$ & 0.317 & 0.279 & 0.250 & 0.280 & 0.293 \\
\hline
\end{tabular}

Note: The table reports the results from Poisson regressions of the number of different categories of relationships. Coefficients: ** Significant at $1 \%$, *Significant at $5 \%$, "Significant at $10 \%$ level. Robust standard errors reported in parentheses. Patent variables are lagged by one period. Details on variable definitions and data sources are provided in Table 1.

non-patenting firms and patents would actually not be decisive for entering a new relationship, we would expect patenting firms to enter more (or less) relationships even in the absence of actual patenting. While this counterfactual situation is unobservable, in our panel, we can observe all patenting firms before they actually receive a patent and define a corresponding "pre-patenting" dummy. If unobserved systematic differences instead of patents lead firms to enter new relationships, we would expect that these differences show up already before a patent has actually been granted. Table 7 presents all models as introduced beforehand, including "pre-patenting" as an additional regressor. Thus, a significant coefficient for this pre-patenting regressor would indicate the presence of a significant selection bias (and the sign for this coefficient would indicate the direction of that bias), while an insignificant coefficient would suggest that whatever bias is present is not particularly significant.

We can see that the results of our baseline specification remain almost completely unchanged, and patenting firms show no sign of entering more or less relationships before they actually receive patents. All coefficients of our "prepatenting" dummy are far away from being statistically significant at any conventional level. These results suggest that unobserved systematic differences of patenting and non-patenting are not a significant source of selection bias in our analysis. 


\subsection{Matching patenting and non-patenting firms}

While the placebo test results are reassuring, we do know that patenting firms differ in some observable characteristics from those firms that do not patent, e.g., position in the ecosystem, age, and size. In order to minimize the influence of these structural differences on our empirical analysis, we balance our sample using "Coarsened Exact Matching” (CEM) (Blackwell et al., 2009). CEM has several features that bind the degree of model dependence, reduce causal estimation error, bias, and inefficiency (Iacus et al., 2009a,b, 2011) (see Younge et al. (2014) and Azoulay et al. (2010) for other applications of CEM). Based on CEM's coarsening function, we match patenting and non-patenting firms on the joint distribution of firm age, size (as measured by customers), our technology indicators, and the firms' position in the ecosystem. ${ }^{17}$ Non-patenting firms that are incomparable to patenting firms are then removed from the sample $(n=262)$. As CEM does not depend on the common support assumption of other matching tools, some patenting firms for which we could not find comparable non-patenting firms were also dropped from the analysis $(n=40)$. The matching procedure reduced the multivariate imbalance of the sample from $L_{1}=0.50$ to $L_{1}=0.017$ ([1 $\left.\leq L_{1} \leq 0\right]$; for a definition of the $L_{1}$ statistic, see Iacus et al., 2011). Finally, we reran our baseline specification on the balanced sample, controlling for any remaining imbalance through according weights derived from CEM. The results are shown in Table 8 .

The estimated effects of patent stock on new entrants' propensity to enter new relationships become more pronounced in terms of magnitude as well as statistical significance in models $a-d$. This points to slight downward biases in our baseline specification in Table 6. With regard to the number of scale-up relationships, we no longer find a significant negative effect, which suggests that the results of the baseline specification might be affected by specific firms with an uncommon combination of characteristics that are incomparable to others. Overall, the results corroborate our main findings.

\subsection{Robustness and sensitivity checks}

We ran several further robustness and sensitivity checks (available upon request). First, we confirmed that all Poisson model estimations are robust to alternative negative binomial model regressions and classic ordinary least squares regressions. Second, we checked whether our Poisson models accurately identify the relatively large fraction of zeros in the data, which might give rise to estimating zero-inflated Poisson or zero-inflated negative binomial models if the model fit would be low. In fact, we found that zeros are pretty accurately identified in all five models (Openness in Innovation, Scientific Research Relationships, Product and Process Relationships, Distribution Relationships, and Scale-up Relationships, with correctly predicted zeros in $94.03 \%, 99.90 \%, 98.05 \%, 97.96 \%, 99.58 \%$ of all cases, respectively). Since zero-inflated models are harder to interpret than Poisson models, require more degrees of freedom, and may lead to inconsistent estimates if the inflation equation is mis-specified, we kept our focus on the reliably consistent Poisson models. Third, in an attempt to control for unobserved time-invariant firm heterogeneity, e.g., managerial quality, we estimated classic random and fixed effects panel data models as well as models including a lagged dependent variable. Random effects models revealed basically the same results as presented. In the fixed effects and lagged dependent variable models, we found the patent stock being always statistically significant and positively associated with the "openness in innovation" and the number of "scientific research relationships," while the coefficients of patenting and "product and process relationships" and "distribution relationships" often appeared with relatively high standard errors, and "scale-up relationships" were never significantly associated with granted patents. We do not want to emphasize these results, as our main variables of interest show limited within-firm variation and estimations are thus prone to attenuation bias.

Finally, we ensured that our results are not driven by a few new entrants that engaged in more than one relationship per year or firms that patented rather frequently. Hence, we first reestimated all previously mentioned models with a dummy variable indicating one or more granted patents up to year $t-1$, instead of the logarithm of the depreciated number of patents, and found qualitatively the same results as presented. Moreover, we estimated the likelihood that new entrants engage in a new relationship in response to the number of granted patents or having at least one patent granted, respectively, using Probit models, where the dependent variable is a dummy indicating

17 We did not match on whether a firm belongs to the "Cleantech 100" group because of a lack of proper controls. The analysis loses much of its statistical power if we enforce a match in this regard (Heckman et al., 1998). All results are robust to an exclusion of the "Cleantech 100 " firms from the analysis. 
Table 8. Relationships and patenting with balanced sample

\begin{tabular}{|c|c|c|c|c|c|}
\hline Dependent variable: & $\begin{array}{c}\text { a } \\
\text { Openness in } \\
\text { Innovation }\end{array}$ & $\begin{array}{c}\text { b } \\
\text { Scientific Research } \\
\text { Relationships }\end{array}$ & $\begin{array}{c}\mathrm{c} \\
\text { Product and Process } \\
\text { Relationships }\end{array}$ & $\begin{array}{c}\mathrm{d} \\
\text { Distribution } \\
\text { Relationships }\end{array}$ & $\begin{array}{c}\text { e } \\
\text { Scale-up } \\
\text { Relationships }\end{array}$ \\
\hline Age & $\begin{array}{l}0.335 * \% \\
(0.169)\end{array}$ & $\begin{array}{l}0.870 * * * \\
(0.231)\end{array}$ & $\begin{array}{c}0.340 \\
(0.253)\end{array}$ & $\begin{array}{c}0.346 \\
(0.329)\end{array}$ & $\begin{array}{r}-0.220 \\
(0.371)\end{array}$ \\
\hline Age sq. & $\begin{array}{r}-0.027 \\
(0.017)\end{array}$ & $\begin{array}{l}-0.072 * * * \\
(0.022)\end{array}$ & $\begin{array}{r}-0.036 \\
(0.025)\end{array}$ & $\begin{array}{r}-0.018 \\
(0.035)\end{array}$ & $\begin{array}{c}0.018 \\
(0.035)\end{array}$ \\
\hline Thin-film & $\begin{array}{c}0.703 \\
(0.518)\end{array}$ & $\begin{array}{c}1.068 \\
(0.998)\end{array}$ & $\begin{array}{c}1.979 * \\
(1.021)\end{array}$ & $\begin{array}{c}0.052 \\
(0.862)\end{array}$ & $\begin{array}{r}-1.106 \\
(1.133)\end{array}$ \\
\hline Other Technologies & $\begin{array}{c}0.633 * \\
(0.373)\end{array}$ & $\begin{array}{c}1.360 \\
(0.989)\end{array}$ & $\begin{array}{c}1.386 \\
(0.906)\end{array}$ & $\begin{array}{r}-0.059 \\
(0.574)\end{array}$ & $\begin{array}{c}0.397 \\
(0.570)\end{array}$ \\
\hline Cleantech 100 & $\begin{array}{l}0.722 * * * \\
(0.261)\end{array}$ & $\begin{array}{l}1.623 * * * \\
(0.449)\end{array}$ & $\begin{array}{l}0.993 * * * \\
(0.366)\end{array}$ & $\begin{array}{c}0.696 \\
(0.460)\end{array}$ & $\begin{array}{r}-0.362 \\
(0.699)\end{array}$ \\
\hline Massachusetts & $\begin{array}{r}-0.260 \\
(0.362)\end{array}$ & $\begin{array}{c}0.011 \\
(0.463)\end{array}$ & $\begin{array}{r}-0.572 \\
(0.659)\end{array}$ & $\begin{array}{r}-0.200 \\
(0.578)\end{array}$ & $\begin{array}{c}-13.770 * * * \\
(0.501)\end{array}$ \\
\hline California & $\begin{array}{c}0.175 \\
(0.199)\end{array}$ & $\begin{array}{r}-0.471 \\
(0.388)\end{array}$ & $\begin{array}{r}-0.027 \\
(0.348)\end{array}$ & $\begin{array}{c}0.567 \\
(0.380)\end{array}$ & $\begin{array}{c}0.688 \\
(0.540)\end{array}$ \\
\hline Log (Customers) & $\begin{array}{l}1.077^{* * *} \\
(0.130)\end{array}$ & $\begin{array}{l}0.700 * * \\
(0.323)\end{array}$ & $\begin{array}{l}1.001 \% * * \\
(0.246)\end{array}$ & $\begin{array}{l}1.068 * * * \\
(0.249)\end{array}$ & $\begin{array}{l}1.438 * * * \\
(0.227)\end{array}$ \\
\hline Material providers & $\begin{array}{r}-0.041 \\
(0.503)\end{array}$ & $\begin{array}{c}0.505 \\
(0.638)\end{array}$ & $\begin{array}{r}-0.359 \\
(0.730)\end{array}$ & $\begin{array}{r}-0.173 \\
(0.664)\end{array}$ & $\begin{array}{r}-0.661 \\
(1.149)\end{array}$ \\
\hline Balance of system & $\begin{array}{c}0.416^{*} \\
(0.239)\end{array}$ & $\begin{array}{c}0.402 \\
(0.385)\end{array}$ & $\begin{array}{c}0.528 \\
(0.384)\end{array}$ & $\begin{array}{c}0.930 * \\
(0.509)\end{array}$ & $\begin{array}{c}-1.006^{*} \\
(0.577)\end{array}$ \\
\hline Integrators & $\begin{array}{c}0.320 \\
(0.313)\end{array}$ & $\begin{array}{r}-0.783 \\
(0.731)\end{array}$ & $\begin{array}{c}0.640 \\
(0.473)\end{array}$ & $\begin{array}{c}0.547 \\
(0.721)\end{array}$ & $\begin{array}{c}0.490 \\
(0.676)\end{array}$ \\
\hline Log (Patent stock) & $\begin{array}{l}0.862 * * * \\
(0.213)\end{array}$ & $\begin{array}{l}1.278^{* * *} \\
(0.245)\end{array}$ & $\begin{array}{l}0.903 * * * \\
(0.286)\end{array}$ & $\begin{array}{l}0.838 * * * \\
(0.309)\end{array}$ & $\begin{array}{r}-0.142 \\
(0.751)\end{array}$ \\
\hline Time fixed effects & yes & yes & yes & yes & yes \\
\hline$N$ & 1170 & 1170 & 1170 & 1170 & 1170 \\
\hline Pseudo $R^{2}$ & 0.290 & 0.160 & 0.226 & 0.355 & 0.287 \\
\hline
\end{tabular}

Note: The table reports the results from Poisson regressions of the number of different categories of relationships. Coefficients: ***Significant at $1 \%$, *Significant at $5 \%$, "Significant at $10 \%$ level. Robust standard errors reported in parentheses. Patent variables are lagged by one period. Details on variable definitions and data sources are provided in Table 1.

engagement in one or more new relationships in a given year. Again, we found statistically as well as economically meaningful support for all our previous results.

\section{Discussion and conclusion}

\subsection{Discussion of main findings}

Our results suggest that formal IP protection (specifically, the receipt of patents) contributes to OI activities of new entrants in the context of a systemic innovation. More specifically, as new entrants accumulate patents, they generally increase their subsequent number of new OI relationships. These findings are in line with the notion that formal IP enables knowledge protection, codification, and provides a useful signaling mechanism for attracting potential collaborators (e.g., Graham and Mowery, 2006; Blind et al., 2006; Hertzfeld et al., 2006; Hsu and Ziedonis, 2013). It signifies that a new entrant has developed a certain stock of useful knowledge, and the presence of a patent enables the new entrant to subsequently share its knowledge without falling victim to the Arrow Disclosure Paradox (Arrow, 1962; Cassimann and Veugelers, 2002).

We interpret these results as supporting the utility of markets for technology (Arora et al., 2001), whereby firms can specialize in one part of a larger system, and obtain some value within that system from its formal IP protection (Teece, 1986). As markets for innovation expand, the returns to specialization increase. Collaborating firms in turn 
can co-specialize, each with its own patents, and use markets to coordinate the co-specialized activities (Mowery et al., 1996). In this context, our results emphasize the "transactional value" of formal IP, whereby IP rights contribute to the locus, and not simply the extent, of investment (Arora and Merges, 2004). Stronger formal IP makes it possible for inputs to be supplied by separate firms and, hence, shifts the locus of innovation beyond the firm's boundaries (Chesbrough, 2003).

An additional important insight from this article is that the association between patent stock and OI is heterogeneous, and that it is crucial to take the underlying contents of OI relationships into account. More specifically, the patent stocks of new entrants particularly drive their OI activities that focus on joint research at the technological frontier. Interestingly, patents are less important for relationships that focus on the development of products and their distribution via market channels, and patents even have a significantly negative effect on relationships that focus on the scaling of existing technologies. These findings are in line with the discussed underlying mechanisms that suggest that patents enable knowledge protection, codification, as well as act as signals of innovative capabilities.

So why do not we see more supporting evidence for freely revealed information that stimulates greater OI (e.g., von Hippel and von Krogh, 2006)? One possibility is that there is indeed significant sharing and free revealing at earlier stages in the formation of firms, and we are only observing activities once firms have incorporated and raised capital. This would suggest that there could be complementary OI processes at work. Initial search for technologies may be advanced by openly sharing information, while more formal protection policies help to attract capital and to translate promising individual learnings into scalable, technologies, products, and services at a later stage (which our archival research design can then observe). Alternatively, firms may combine formal OI relationships that are supported by patents with informal networks, in which employees disclose information under the assumption of reciprocity (Schrader, 1991). Similarly, firms may align their product architecture with IP and thereby establish "IP modularity," which allows them to formally protect certain modules while freely revealing others (Henkel et al., 2013).

Other possible explanations may relate to the nature of the specific industry and technology that we investigate. Others have noted the distinction between autonomous and systemic technologies (Chesbrough and Teece, 1996). Furthermore, prior work suggests that the role of patents may be different in the context of concrete or autonomous product industries and cumulative system technologies (Pavitt, 1984; Mazzoleni and Nelson, 1998). Our theory development is positioned within the context of systemic technologies and innovation. Accordingly, our empirical context-the solar industry-is an excellent example of such an industrial setting, as it involves many complex piece parts that must be carefully integrated to function effectively. Joint efforts by material providers, cell manufacturers, balance-of-system-providers, and solar system integrators are required for technologically enabling solar systems and making them economically attractive. Furthermore, utilities, governments, cities, and other regulatory bodies are essential for enabling the installation of commercial and residential solar structures. These requirements are beyond the capability of individual innovators. This makes solar a systemic technology, according to the definition above, limiting the extent to which even a highly motivated user can innovate directly for his or her own benefit. Autonomous technologies, by contrast, may allow more independent innovation by freely revealing actors, who can benefit directly from their effort. Hence, the role of open exchange and free revealing may be a different one in a context where individual- and community-based innovation processes are viable (e.g., von Hippel and Katz, 2002) or where the presence of industry standards reduces systemic interdependencies in an industry.

\subsection{Implications for Ol Research}

Together, our results shed some light on the dichotomy in the literature that splits the field into those suggesting that formal IP enables OI (e.g., Chesbrough, 2003, 2006) and those suggesting that sharing and free revealing-as opposed to formal IP_drive OI (e.g., von Hippel and von Krogh, 2006; Baldwin and von Hippel, 2011). In general, our results are in line with the former perspective: we find that IP in the form of patent stock increases new entrants' subsequent number of OI relationships. However, our results also reveal that this relationship is not of a uniform nature. Instead, a more fine-grained analysis demonstrates that this enabling effect is most important for technologyintensive relationships and less important for relationships of decreasing technology intensity. Even more so, patent stock may indeed hinder relationships that are closest to the market-those that focus on the scaling of new innovations. These nuanced findings contribute to the existing literature on the association of IP and OI or collaborative R\&D, which has differentiated between external search breadth and depth (Laursen and Salter, 2014; Hagedoorn 
et al., 2014) and partner types (Henttonen et al., 2016) but has not discriminated between contents of OI relationships.

Besides shedding some light on the fundamental dichotomy regarding the function of formal IP for OI, this research makes several important contributions to the emerging field of OI. First of all, to our knowledge, this study is among the first to investigate OI in the context of new entrants (see Ganotikas and Love, 2012, for a notable exception). While recent surveys of OI examine the prevalence of OI in the context of large firms (Chesbrough and Brunswicker, 2013), research on OI in the context of new entrants is scarce (see Colombo et al., 2016, for a notable exception). However, the question of whether patenting enables OI is particularly relevant for this type of firm, as OI may be crucial for new entrants to overcome their resource constraints and fully deploy their capacity for disruptive and systemic innovation. Our results highlight that, overall, patents enable new entrants to enter into a larger number of OI relationships and thereby facilitate their access to complementary innovation resources. These insights add to and extend prior literature that investigates the features of firms that relate to their participation in interorganizational relationships (e.g., Hagedoorn, 1993; Tether, 2002; Garriga et al., 2013).

Second, we extend existing empirical OI research that is largely based on general innovation surveys, such as the Community Innovation Survey (e.g., Laursen and Salter, 2006, 2014) by assembling an archival database that captures the actual OI relationship behavior of firms. In this context, we go beyond external search openness to try to advance existing research by operationalizing and analyzing the actual contents of interorganizational relationships. Our findings emphasize the importance of disentangling the underlying contents of OI relationships that vary in terms of technology intensity. One size does not fit all: we find substantial heterogeneity in the associations between patenting and OI relationships that focus on the exchange of different types of resources that vary in terms of technology intensity.

Similarly, in addressing the association between IP and OI, we consider firms' actual stock of IP in the form of patents granted. Hence, we observe and investigate what happens when firms actually receive IP rights. Our specific research context of new entrants enables us to better disentangle the effect of actual patent stocks on subsequent OI activities. Thereby, insights from this study add to and complement prior work that has examined associations between firms' general preferences regarding IP and OI (Laursen and Salter, 2014; Hagedoorn et al., 2014; Hagedoorn and Zobel, 2015).

\subsection{Policy and managerial implications}

Our findings add to the discussion of the costs and benefits regarding strong patent protection and therefore have important policy implications. Concerns have frequently been raised about the current status of the patenting system and the degree to which it might hinder innovation, especially by placing young innovative firms at a disadvantage (e.g., Hoenen et al., 2014). This article extends this traditional question regarding the effectiveness of patents for innovation (e.g., Mazzoleni and Nelson, 1998) to the context of OI. Our findings suggest that patents can be important mechanisms for enabling OI relationships. Hence, besides their isolating function that aims at incentivizing private investment in innovation, in the context of OI, patents may incorporate an additional function in terms of encouraging collaborative innovation.

From a policy perspective, the impact of patenting on OI is of particular interest in the context of systemic industries that are dependent on the joint innovative efforts of various parties. We argued that the solar industry is a particularly interesting example of such a systemic innovation context. It is an industry that has attracted a lot of attention from policy makers, who wish to accelerate innovation in the industry to increase the use of renewable, carbon-free energy sources. It is an industry that has experienced a significant increase in basic research, with the US Department of Energy alone investing more than $\$ 30$ billion of new funds as part of the 2009 budget. It is an industry that has attracted a significant amount of venture capital financing in the past decade (though this level of investment has been curtailed in the last few years). And, it is an industry with many complex technologies that must be coordinated together in order to deliver value to customers and to society. For all these reasons, one would truly like to know whether stronger IP protection helps or hinders OI in this context. Our results suggest that patenting enables OI relationships in the solar industry, and we believe that these results are generalizable to other systemic innovation settings.

Our results also have managerial implications, particularly for new entrants. Since new entrants operating in a systemic innovation context are often dependent on external partners for achieving radical innovations, it is 
important for them to know whether patenting enables collaborative efforts. We find that patenting leads to an increased number of OI relationships and, therefore allows new entrants to access complementary resources, particularly those that are more technology intensive. Furthermore, for new entrants, who are often disadvantaged by the patent system and for whom the patenting process is particularly costly and time-consuming, a critical evaluation of the value and functions of patents seems crucial. Our findings suggest that new entrants may want to include one or more patents in their entry strategy, particularly, if they aim at engaging in technology intensive collaborations.

\subsection{Limitations and future research}

Our study is subject to the usual concerns of single industry studies based on archival data. For instance, our data sources may not be complete. We did employ a second data source (Lexis-Nexis) to corroborate the archival data we used, but some gaps may remain nonetheless. As mentioned above, we mainly observe publicly announced formal relationships. More informal processes that likely took place are unobservable to us. Furthermore, our empirical setting is restricted to the solar industry that is characterized by a high growth rate in patenting and high capital costs required to scale up production and distribution. Our results may not be generalizable to other industries in which patenting and capital costs are less salient. Finally, we only observed new entrants in North America. This is a limitation in interpreting these results in the context of other regions, such as Europe or Asia. Additionally, our analysis cannot resolve all concerns about the causal impact of patent stock on OI activities of new entrants. Future research that is able to exploit a natural experiment or exogenous shock to the patenting behavior of firms would provide a more precise estimation of the patenting-OI relationship. We do feel, however, that our archival design represents a methodological improvement over earlier self-reported survey data.

Furthermore, a number of theoretical shortcomings merits further research on this topic. First of all, this study does not determine which specific underlying mechanisms drive the empirical results. It is not clear whether it is the protection, codification, or signaling function that primarily drives the effect of patenting on OI. Various contingencies may shape the relevance of these three mechanisms. For instance, in very turbulent and dynamic innovation environments, given the lengthy patenting process, patents may be less relevant for protecting the most recent, cuttingedge knowledge. Similarly, codification in such settings may be less significant, as patent issuance delays mean that patents no longer reflect the state-of-the-art knowledge that is shared in OI relationships. In such a context, signaling of general innovative capabilities might be the strongest explanatory mechanism. Furthermore, the strengths of our proposed mechanisms are likely to differ across OI relationships that are characterized by inbound, outbound, or coupled knowledge flows. For instance, protection is likely to be more relevant for outbound than for inbound knowledge flows, as firms are more concerned about imitation when they let knowledge flow outside their boundaries. Codification may be most relevant in the context of coupled OI in which partners create and mutually exchange new knowledge. Signaling may be essential for attracting outbound and coupled OI activities, but may be less relevant for initiating inbound OI relationships, in which partner firms do not source any knowledge from the focal firm. Hence, future research is needed to clarify the relevance of these mechanisms under various conditions.

Finally, recent literature has emphasized a portfolio thinking of IP, according to which patenting constitutes only one out of several appropriation mechanisms within a broader appropriability regime (e.g., Somaya, 2012; James et al., 2013; Henttonen et al., 2016). This regime does not only include formal mechanisms such as patenting, but also informal mechanisms such as trust or secrecy. Formal mechanisms and, in particular, patents may be inappropriate for protecting certain types of knowledge, such as newly generated, cutting-edge scientific knowledge. As patenting involves a lengthy process, such types of knowledge likely need to be protected by alternative means, such as complexity or secrecy. In this context, future research should investigate the effect of other formal and informal appropriation mechanisms on OI, as well as potential interaction effects between these mechanisms. Along these lines, it will be important to investigate how firms can choose between various formal and informal options in designing their appropriability regime in an OI context.

\section{Acknowledgements}

We would like to thank the editor and two anonymous reviewers for the Industrial and Corporate Change special section on Open Innovation for their helpful guidance and valuable suggestions. We would like to particularly thank John Hagedoorn for his in-depth comments on an earlier version of this article. We are also grateful to Guan-Cheng Li for his help in providing the patent data. The 
article has also benefited from suggestions made by participants at the Stanford SIEPR seminar, the Berkeley Open Innovation seminar, and the first World Open Innovation Conference.

\section{References}

Adner, R. and Kapoor R. (2010), 'Value creation in innovation ecosystems: how the structure of technological interdependence affects firm performance in new technology generations,' Strategic Management Journal, 31(3), 306-333.

Afuah, A. and Tucci C. (2000), Internet Business Models and Strategies: Text and Cases. Irwin/McGraw-Hill: New York, NY.

Alexy, O., Criscuolo P. and Salter A. (2009), 'Does IP strategy have to cripple open innovation?,' MIT Sloan Management Review, 51(1), 71-77.

Alexy, O., Bascavusoglu-Moreau E. and Salter A. J. (2016), 'Toward an aspiration-level theory of open innovation,' Industrial and Corporate Change, 25(2), 289-306.

Anton, J. J. and Yao D. A. (2004), 'Little patents and big secrets: managing intellectual property,' RAND Journal of Economics, 35, $1-22$.

Arora, A. and Merges R. P. (2004), 'Specialized supply firms, property rights and firm Boundaries,' Industrial and Corporate Change, 13(3), 451-475.

Arora, A., Fosfuri A. and Gambardella A. (2001), 'Markets for technology and their implications for corporate strategy,' Industrial and Corporate Change, 10(2), 419-451.

Arrow, K. J. (1962), 'Economic welfare and the allocation of resources for invention,' in Arrow K. J. (ed.), The Rate and Direction of Inventive Activity. Princeton University Press: Princeton, NJ.

Azoulay P., Zivin J. and Wang J. (2010), 'Superstar extinction,' Quarterly Journal of Economics, 125(2), 549-589.

Bae, J. and Gargiulo M. (2004), 'Partner substitutability, alliance network structure, and firm profitability in the telecommunications industry,' The Academy of Management Journal, 47(6), 843-859.

Baldwin, C. and Hippel E. von (2011), 'Modeling a paradigm shift: from producer innovation to user and open collaborative innovation,' Organization Science, 22(6), 1399-1417.

Blackwell M., Iacus S., King G. and Porro G. (2009), 'CEM: coarsened exact matching in Stata,' Stata Journal, 9(4), 524-546.

Blind, K., Edler J., Frietsch R. and Schmoch U. (2006), 'Motives to patent: Empirical evidence from Germany,' Research Policy, 35, 655-672.

California Public Utilities Commission (2013), ‘California Solar Initiative Program Handbook’ (April).

Carroll, G. R. and Hannan M. T. (1989), 'Density delay in the evolution of organizational populations: a model and five empirical tests,' Administrative Science Quarterly, 34, 411-430.

Cassimann, B. and Veugelers R. (2002), 'R\&D cooperation and spillovers: some empirical evidence from Belgium,' The American Economic Review, 92(4), 1169-1184.

Chesbrough, H. W. (2003), Open Innovation: The New Imperative for Creating and Profiting from Technology. Harvard Business School Press: Boston, MA.

Chesbrough, H. W. (2006), Open Business Models: How to Thrive in the New Innovation Landscape. Harvard Business School Press: Boston, MA.

Chesbrough, H. W. and Teece D. J. (1996), 'When is virtual virtuous? Organizing for innovation,' Harvard Business Review, 74(1), $65-73$.

Chesbrough, H. W. and Brunswicker S. (2013), Managing Open Innovation in Large Firms - Executive Survey on Open Innovation. Fraunhofer Verlag: Stuttgart, Germany.

Chesbrough, H. W. and Bogers M. (2014), 'Explicating open innovation - clarifying an emerging paradigm for understanding innovation,' in Chesbrough H. W., Vanhaverbeke W. and West J. (eds), New Frontiers in Open Innovation. Oxford University Press: Oxford, UK.

Chesbrough, H. W., Vanhaverbeke W. and West J. (2014), New Frontiers in Open Innovation. Oxford University Press: Oxford, UK. Christensen, J. F. (1995), 'Asset profiles for technological innovation,' Research Policy, 24, 727-745.

Christensen, J. F., Olesen M. H. and Kjaer J. S. (2005), 'The industrial dynamics of open innovation - evidence from the transformation of consumer electronics,' Research Policy, 34, 1533-1549.

Cohen, W. M., Nelson R. and Walsh J. (2000), 'Protecting their intellectual assets - appropriability conditions and why U.S. manufacturing firms patent or not,' National Bureau of Economics Research Working Paper No. 7552.

Colombo, M. G., Cumming D. J., Mohammadi A., Rossi-Lamastra C. and Wadhwa A. (2016), 'Open business models and venture capital financing,' Industrial and Corporate Change, 25(2).

Czarnitzki, D. and Toole A. A. (2011), 'Patent protection, market uncertainty, and R\&D investment,' The Review of Economics and Statistics, 93(1), 147-159.

de Man, A. P. (2004), The network economy. Strategy, structure and management. Edward Elgar: Cheltenham, UK.

Du, J., Leten B. and Vanhaverbeke W. (2014), 'Managing open innovation projects with science-based and market-based partners,' Research Policy, 43(5), 828-840. 
Dubiansky, J. (2006), 'The role of patents in fostering open innovation,' Virginia Journal of Law and Technology, 11(7), 1-36.

Foss, N. J., Laursen K. and Pedersen T. (2011), 'Linking customer interaction and innovation: the mediating role of new organizational practices,' Organization Science, 22(4), 980-999.

Ganotikas, P. and Love J. H. (2012), 'The innovation value chain in new technology-based firms: Evidence from the U.K.' Journal of Product Innovation Management, 29(5), 839-860.

Garriga, H., Krogh G. von and Spaeth S. (2013), 'How constraints and knowledge impact open innovation,' Strategic Management Journal, 34(9), 1134-1144.

Graham, S. J. H., Merges R. P., Samuelson P. and Sichelman T. (2009), 'High technology entrepreneurs and the patent system: results of the 2008 Berkeley patent survey,' 24 Berkeley Tech. L.J. 1255 (2009), Available at http://scholarship.law.berkeley.edu/facpubs/ 2124.

Graham, S. J. H. and Mowery D. C. (2006), 'The use of intellectual property in software: implications for open innovation,' in Chesbrough H. W., Vanhaverbeke W. and West J. (eds), Open innovation: Researching a New Paradigm. Oxford University Press: Oxford, UK, pp. 109-133.

Griliches, Z. and Mairesse J. (1984), 'Productivity and R\&D at the firm level,' in Griliches Z. (ed.), R \&D, Patents and Productivity. University of Chicago Press: Chicago, IL, pp. 339-374.

Grimpe, C. and Sofka W. (2009), 'Search patterns and absorptive capacity: low- and high-technology sectors in European countries,' Research Policy, 38, 495-506.

Gulati, R., Lavie D. and Singh H. (2009), 'The nature of partnering experience and the gains from alliances,' Strategic Management Journal, 30, 1213-1233.

Hagedoorn, J. (1993), 'Understanding the rationale of strategic technology partnering: interoganizational modes of cooperation and sectoral differences,' Strategic Management Journal, 15(5), 371-385.

Hagedoorn, J. and Zobel A. (2015), 'The role of contracts and intellectual property rights in open innovation,' Technology Analysis and Strategic Management, 27(9), 1050-1067.

Hagedoorn, J., Lokshin B. and Zobel A. (2014), 'The co-alignment of open innovation with environmental contingencies and its effect on innovation performance,' Maastricht University Working Paper.

Hall, B. H. (1990), 'The manufacturing sector master file: 1959-1987,' NBER Working Paper No. 3366. Cambridge, MA.

Hall, B. R. and Ziedonis R. (2001), 'The patent paradox revisited: an empirical study of patenting in the U.S. semiconductor industry, 1979-1995,' The RAND Journal of Economics, 32(1), 101-128.

Hansen, M. T. and Birkinshaw J. (2007), 'The innovation value chain,' Harvard Business Review, 85(6), 121-130.

Heckman, J. J., Ichimura H. and Todd P. (1998), 'Matching as an econometric evaluation estimator,' Review of Economic Studies, 65(2), 261-294.

Henkel, J., Baldwin C. and Shih W. (2013), 'IP modularity: profiting from innovation by aligning product architecture with intellectual property,' California Management Review, 55(4), 65-82.

Henttonen, K., Hurmelinna-Laukkanen P. and Ritala P. (2015), 'Managing the appropriability of R\&D collaboration,' R\&D Management, 46, 141-158. http://onlinelibrary.wiley.com/doi/10.1111/radm.12121/abstract

Hertzfeld, H. R., Link A. N. and Vonortas N. S. (2006), 'Intellectual property mechanisms in research partnerships,' Research Policy, 36, 825-838.

Hoenen, S., Kolympiris C., Schoenmakers W. and Kalaitzandonakes N. (2014), 'The diminishing signaling value of patents between early rounds of venture capital financing,' Research Policy, 43(6), 956-989.

Hoffman, W. H. (2007), 'Strategies for managing a portfolio of alliances,' Strategic Management Journal, 28(8), 827-856.

Hsu, D. H. and Ziedonis R. H. (2013), 'Resources as dual sources of advantage: implications for valuing entrepreneurial-firm patents,' Strategic Management Journal, 34, 761-781.

Hurmelinna, P., Kyläheiko K., and Jauhiainen T., (2007), 'The janus face of the appropriability regime in the protection of innovations: theoretical re-appraisal and empirical analysis,' Technovation, 27, 133-144.

Iacus, S. M., King G. and Porro G. (2009a), 'Causal inference without balance checking: coarsened exact matching,' Political Analysis, Copy at http://gking.harvard.edu/cem.

Iacus, S. M., King G. and Porro G. (2009b), 'CEM: software for coarsened exact matching,' Journal of Statistical Software, 30(9), 1-27.

Iacus, S. M., King G. and Porro G. (2011), 'Multivariate matching methods that are monotonic imbalance bounding,' Journal of the American Statistical Association, 106(493), 345-361.

James, S. D., Leiblein M. J., and Lu S., (2013), 'How firms capture value from their Innovations,' Journal of Management, 39(5), 1123-1155.

Kapoor, R. and Furr N. R. (2014), 'Complementarities and competition: unpacking the drivers of entrants' technology choices in the solar photovoltaic industry,' Strategic Management Journal, Published Online Early View, DOI:10.1002/smj.2223

King, A. A., Tucci C. L. (2002), 'The role of experience and managerial choice in the creation of dynamic capabilities,' Management Science, 48(2), 171-186. 
Köhler, C., Sofka W. and Grimpe C., (2012), 'Selective search, sectoral patterns, and the impact on product innovation performance,' Research Policy, 41, 1344-1356.

Lakemond, N., Bengtsson, K., Laursen, K. and Tell F. (2016), 'Match \& Manage: the use of knowledge matching and project management to integrate knowledge in collaborative inbound open innovation,' Industrial and Corporate Change, 25(2).

Laursen, K. and Salter A., (2006), 'Open for innovation: the role of openness in explaining innovation performance among U.K. manufacturing firms,' Strategic Management Journal, 27, 131-150.

Laursen, K. and Salter A., (2014), 'The paradox of openness: appropriability, external search and collaboration,' Research Policy, 43(5), 867-878.

Lawson, B., Samson D., and Roden S., (2012), 'Appropriating the value from innovation: inimitability and the effectiveness of isolating mechanisms,' RむD Management, 42(5), 420-434.

Lee, S., Park G., Yoon B. and Park J., (2010), 'Open innovation in SMEs - an intermediated network model,' Research Policy, 39, 290-300.

Love, J. H., Roper S. and Bryson J. R., (2011), 'Openness, knowledge, innovation and growth in UK business services,' Research Policy, 40, 1438-1452.

Love, J. H., Roper S. and Vahter P., (2013), 'Learning from openness: the dynamics of breadth in external innovation linkages,' Strategic Management Journal, 35(11), 1703-1716.

Mazzoleni, R. and Nelson R. R., (1998), 'The benefits and costs of strong patent protection: a contribution to the current debate,' Research Policy, 27, 273-284.

Möller, K. and Rajala A., (2007), 'Rise of strategic nets - New modes of value creation,' Industrial Marketing Management, 36, 895-908.

Mowery, D. C., Oxley J. E., and Silverman B. S., (1996), 'Strategic alliances and interfirm knowledge transfer,' Strategic Management Journal, 17, 77-91.

Nanda, R., Younge K. and Fleming L., (2014), 'Innovation and entrepreneurship in renewable energy,' in NBER Chapters in: The Changing Frontier: Rethinking Science and Innovation Policy. NBER: New York, NY.

Olander, H., Hurmelinna-Laukkanen P., Blomqvist K., and Ritala P., (2010), 'The dynamics of relational and contractual governance mechanisms in knowledge sharing of collaborative R\&D projects,' Knowledge and Process Management, 17, 188-204.

Overholm, H. (2015), 'Collectively created opportunities in emerging ecosystems: the case of solar service ventures,' Technovation, 39-40, 14-25.

Parida, V., Westerberg M., and Frishammar J., (2012), 'Inbound open innovation activities in high-tech SMEs: the impact on innovation performance,' Journal of Small Business Management, 50(2), 283-309.

Pavitt, K. (1984), 'Sectoral patterns of technical change: towards a taxonomy and a theory,' Research Policy, 13, 343-373.

Pénin, J., Hussler C., and Burger-Helmchen T., (2011), 'New shapes and new stakes: a portrait of open innovation as a promising phenomenon,' Journal of Innovation Economics, 7, 11-29.

Pisano, G. P. and Teece D. J., (2007), 'How to capture value from innovation: shapingintellectual property and industry architecture,' California Management Review, 50(1), 278-295.

Prencipe, A., Davies A. and Hobday M., (2003), The Business of System Integration. Oxford University Press: Oxford, UK.

Ritala, P. and Hurmelinna-Laukkanen P., (2013), 'Incremental and radical innovation in coopetition - the role of absorptive capacity and appropriability,' Journal of Product Innovation Management, 30(1), 154-169.

Roper, S., Vahter P., and Love J. H., (2013), 'Externalities of openness in innovation,' Research Policy, 42(9), $1544-1554$.

Rothaermel, F. T. (2001), 'Incumbent's advantage through exploiting complementary assets via interfirm cooperation,' Strategic Management Journal, 22(6-7), 687-699.

Sammarra, A. and Biggiero L., (2008), 'Heterogeneity and specificity of inter-firm knowledge flows in innovation networks,' Journal of Management Studies, 45(4), 800-829.

Schrader, S. (1991), 'Informal technology transfer between firms: cooperation through information trading,' Research Policy, 20, 153-170.

Somaya, D. (2012), 'Patent strategy and management: an integrative review and research Agenda,' Journal of Management, 38(4), 1084-1114.

Teece, D. (1986), 'Profiting from technological innovation: implications for integration, collaboration, licensing and public policy,' Research Policy, 15(6), 285-305.

Tether, B. S. (2002), 'Who co-operates for innovation, and why: an empirical analysis,' Research Policy, 31, 947-967.

Veer, T. and Jell F., (2012), 'Contributing to markets for technology? A comparison of patent filing motives of individual inventors, small companies and universities,' Technovation, 32, 513-522.

Van de Vrande, V., de Jong J. P. J., Vanhaverbeke W. and Rochemont M. de, (2009), 'Open innovation in SMEs: trends, motives and management challenges,' Technovation, 29, 423-437.

Von Hippel, E. and Katz R., (2002), 'Shifting innovation to users via toolkits,' Management Science, 48(7), 821-833.

Von Hippel, E. and Krogh G. von, (2006), 'Free revealing and the private-collective model for innovation incentives,' $R \mathcal{G} D$ Management, 36(3), 295-306. 
West, J. (2006), 'Does appropriability enable or retard open innovation?,' in Chesbrough, H., Vanhaverbeke W. and West J., (eds), Open Innovation: Researching a New Paradigm. Oxford University Press: Oxford, UK.

West, J. and Bogers M., (2014), 'Leveraging external sources of innovation: a review of research on open innovation,' Journal of Product Innovation Management, 31(4), 814-831.

West, J. and Gallagher S. (2006), 'Patterns of open innovation in open source software,' in Chesbrough, H. W., Vanhaverbeke W. and West J. (eds), Open Innovation: Researching a New Paradigm. Oxford University Press: Oxford, UK, pp. 22-106.

Wu, C. -Y. and Mathews J. A. (2012), 'Knowledge flows in the solar photovoltaic industry: insights from patenting by Taiwan, Korea, and China,' Research Policy, 41, 524-540.

Younge, K., Tong T. and Fleming L., (2014), 'How anticipated employee mobility affects acquisition likelihood: evidence from a natural experiment,' Strategic Management Journal, 36(5), 686-708.

Zellner, A. and Huang D. S. (1962), 'Further properties of efficient estimators for seemingly unrelated regression equations,' International Economic Review, 3, 300-313. 